\title{
Starch and Glycogen Analyses: Methods and Techniques
}

\author{
Henrike Brust ${ }^{1}$, Slawomir Orzechowski ${ }^{2}$ and Joerg Fettke ${ }^{3, *}$ (D) \\ 1 Leibniz Institute for Plasma Science and Technology, Institute of Biochemistry and Biology, \\ Felix-Hausdorff-Str. 2, 17489 Greifswald, Germany; henrike.brust@inp-greifswald.de \\ 2 Department of Biochemistry and Microbiology, Warsaw University of Life Sciences-SGGW, ul. \\ Nowoursynowska 159 Budynek 37 P/12B, 02-776 Warszawa, Poland; slawomir_orzechowski@sggw.edu.pl \\ 3 Biopolymer Analytics, Institute of Biochemistry and Biology, University of Potsdam, Karl-Liebknecht-Str. \\ 24-25 Building 20, 14476 Potsdam-Golm, Germany \\ * Correspondence: fettke@uni-potsdam.de
}

Received: 13 May 2020; Accepted: 7 July 2020; Published: 9 July 2020

check for updates

\begin{abstract}
For complex carbohydrates, such as glycogen and starch, various analytical methods and techniques exist allowing the detailed characterization of these storage carbohydrates. In this article, we give a brief overview of the most frequently used methods, techniques, and results. Furthermore, we give insights in the isolation, purification, and fragmentation of both starch and glycogen. An overview of the different structural levels of the glucans is given and the corresponding analytical techniques are discussed. Moreover, future perspectives of the analytical needs and the challenges of the currently developing scientific questions are included.
\end{abstract}

Keywords: starch; glycogen; analytics

\section{Introduction}

Today, several techniques for the analysis of complex carbohydrates exist, though a single all-embracing method is lacking. All methods provide information about glycan samples, but along with this knowledge, there is unfortunately also a partial loss of specific information. As an example, very large and complex glycans can be analyzed only following partial fragmentation. Thus, a combination of several methods is required for extensive characterization of glycans. Furthermore, the use of overlapping methods is the most promising approach. Therefore, in this article, several competing techniques are presented, essentially restricted to the analytics of the complex storage glucans, starch, and glycogen. However, as starch and glycogen have very similar chemical properties but strongly different physical characteristics, this article starts with a focus on the required differences in the analytical workflow for both glucans. Following this, the different levels of analyses are summarized and discussed. However, many different conventional and modern analytical techniques exist, and thus, we constrain our discussion to the most widespread state-of-the-art methods and techniques.

\section{Structural Organization and Differences between Starch and Glycogen}

Starch, which is composed of two glucose polymers, amylopectin and amylose, and glycogen serve as important reserve polysaccharides for the storage of carbon and energy in many species among Eukaryota, Bacteria, and Archaea [1,2]. The glucan polymers consist of $\alpha$-D-glucosyl residues, connected via $\alpha 1,4$ and $\alpha 1,6$ glycosidic bonds. $\alpha 1,4$ glucan chains are connected via $\alpha 1,6$ linkages. While both, starch and glycogen, are chemically identical, major differences in their physicochemical properties are related to the molecular organization of glucan chains within the molecules. In starch, branching points are clustered, in contrast to glycogen, resulting in longer linear glucan chains, that can 
form double helices and water is excluded. Organization of double helices within amylopectin results in mainly two crystalline allomorphs (type A and B) (see also Figure 1) [3-7]. As a general consequence, starch and glycogen differ in their water solubility. Starch consists of branched water insoluble semi-crystalline amylopectin, and the nearly linear amylose is probably interspersed within the amorphous regions of amylopectin [8-10]. Glycogen, in contrast, is mostly watersoluble. Starch shows a relative high density of approximately $1.5 \mathrm{gcm}^{-3}$. Consequently, the isolation methods for starch and glycogen also differ (see Section 2).

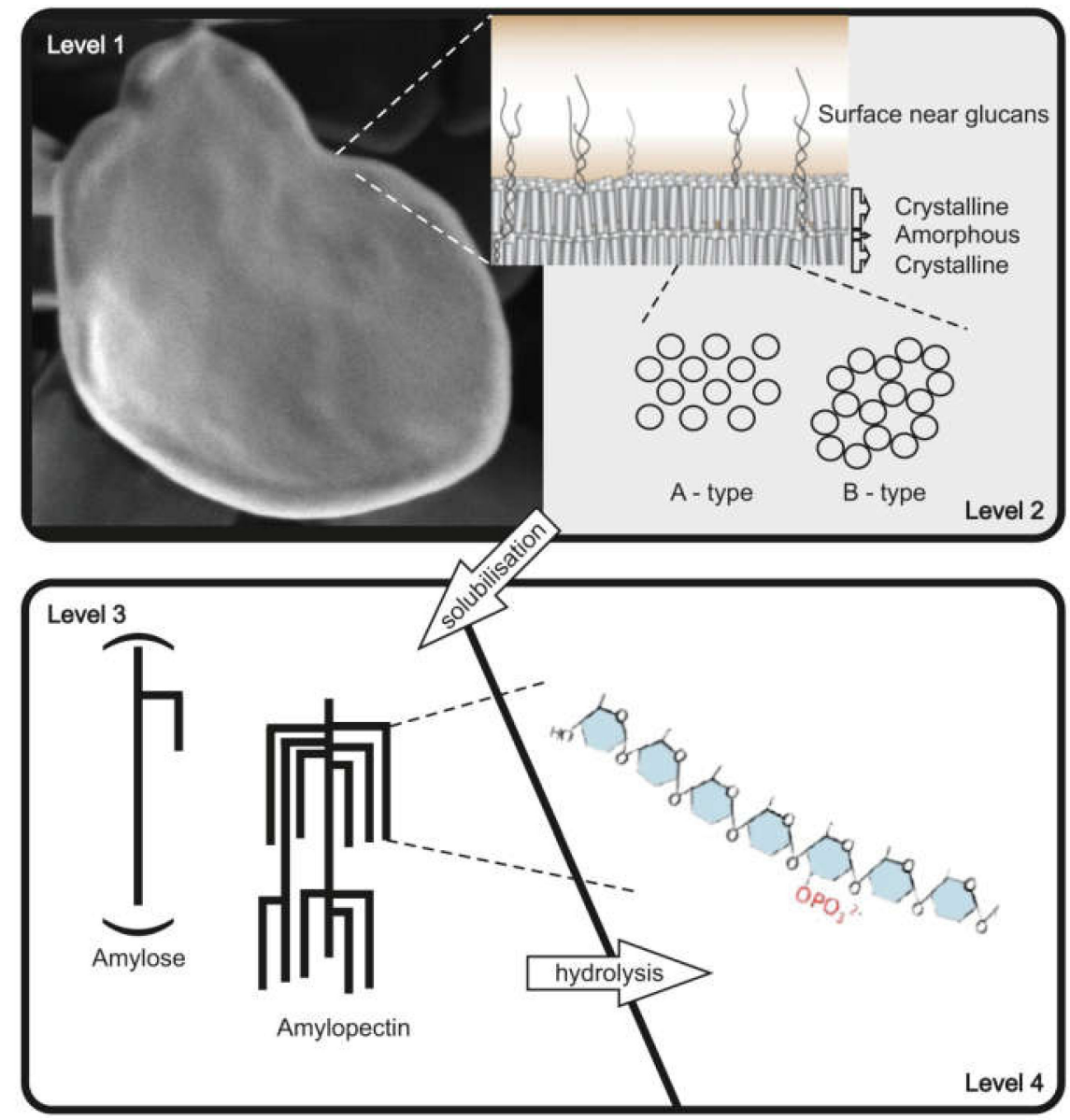

Figure 1. The complex hierarchical structure of starch. At least four levels can be distinguished. Level 1 represents the microscopic level of starch granules and in parts also surface properties. Level 2 reflects the inner starch structure and further information about the starch granule surface. Thus, it is necessary to distinguish between surface, crystalline, and amorphous regions. Furthermore, the crystalline regions can be organized in two major types of allomorph A and B. The level 3 represents the description of entire amylose and amylopectin molecules. Please notice, that amylose chains are much longer than amylopectin chains; this is indicated by showing only a section of amylose. The intra molecular description represents the level 4. For more information regarding starch structure, please see also [11].

Both polymers, glycogen and starch, can be described and characterized on different structural levels, but as a consequence of the difference in complexity, the necessary levels for comprehensive characterization differ. For starch, at least four levels of structural description can be distinguished (Figure 1), whereas for glycogen, using the same structural levels, three are mostly sufficient (Table 1). Different techniques are necessary to analyze the varying structural levels (Table 1). However, a further consequence of the semi-crystalline structure of starch, in contrast to glycogen, is the necessity of solubilization. Only by solubilization of the starch granules can the structural levels 3 and 4 be analyzed. 
Table 1. Levels of molecular and supra molecular structure organization.

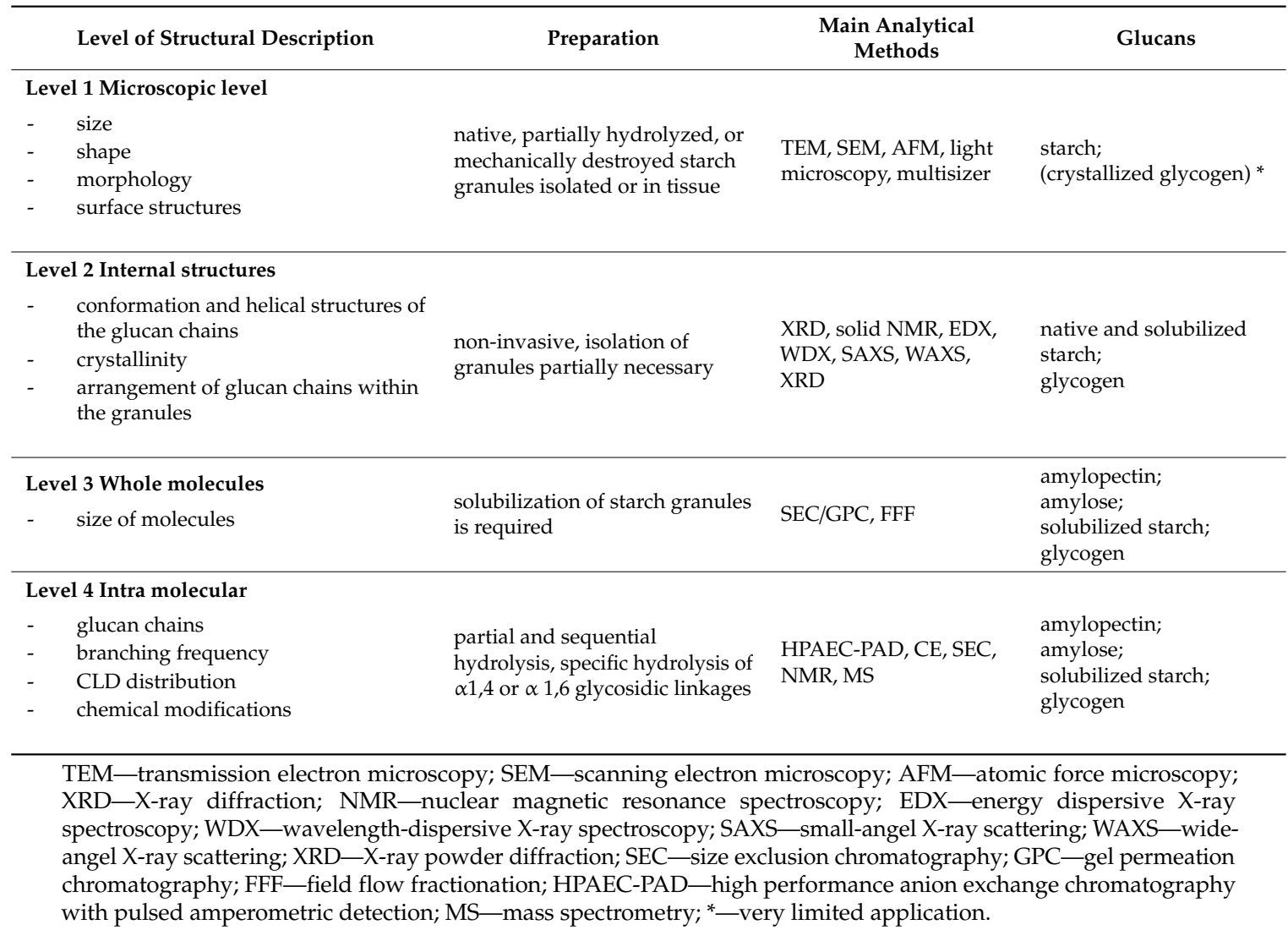

\section{Isolation from Tissue and Quantification of Starch and Glycogen}

The generation of the homogenate is critical, as this is dependent on the tissue from which starch or glycogen is to be isolated. Transitory starch, isolated from leaves, is mostly obtained by first homogenizing frozen leaf material with mortar and pestle in liquid nitrogen following further homogenization with a blender [12-14] or using an all-glass homogenizer in presence of perchloric acid [15]. Isolation of storage starch is more heterogeneous as the organs and tissues differ largely. Homogenization of starch storing tissues by cutters, cryogrinder, mills, or blenders is widespread [16-21]. The extraction procedure is often combined with chemical or enzymatic treatments to remove proteins, lipids, and non-starch related carbohydrates $[19,22,23]$. The generation of artificial glycogen and starch species by partial destruction is to be avoided. Furthermore, an inactivation of starch endogenous enzymes (e.g., by using detergence) to prevent alterations of the glucan structure is advisable. Therefore, different adaptations are necessary for every tissue.

Following homogenization, the starch, as water insoluble particles can be easily separated from most proteins, nucleic acids, lipids, and soluble sugars by aqueous extraction and following centrifugation. Additional filtration via mesh and density gradients (e.g., Percoll) is frequently used [24-26]. However, thus far, it is unclear if this treatment is also accompanied by an unwanted granule size selection and/or by a loss of structural information, at least at the starch granule surface. Therefore, the data obtained regarding the starch granule surface should be critically reviewed.

The isolation of glycogen is more complex, as glycogen is watersoluble, similar to potential contaminating proteins and further metabolites. For the extraction of glycogen from mammal liver or muscles, the trichloroacetic acid (TCA)-based isolation procedures or ultracentrifugation in combination with sucrose gradients are widely used (TCA, [27,28]; sucrose, [29-31]). Isolation of glycogen from bacteria can be achived via sonification or a French press to disrupt the cell wall. Here, cell debris are centrifuged and the supernatant containing glycogen is precipitated with ethanol or ethanol in 
combination with $\mathrm{KCl}$ or $\mathrm{LiCl}[32,33]$. In some cases, glycogen can become insoluble as e.g., in case of Lafora disease [34], and this has an impact on the further isolation, that is more similar to that of starch.

In several plant mutants affected in starch metabolism, due to the loss or reduction in starch debranching enzymes, especially isoamylases, is phytoglycogen [35-39]. It is characterized by its high similarity to glycogen, but its origin is from plants. Similar to glycogen, it is watersoluble, and thus, its isolation procedure is comparable. However, it can also include further isolation steps using perchloric acid or fractionation via size exclusion chromatography [38,40-44].

The determination of the starch or glycogen amount in a specific tissue, organ or entire living system does not inevitably include the isolation of the glucans. Thus, for starch as well as for glycogen, enzymatic and non-enzymatic procedures exist, allowing the approximate determination of the content following destruction of the biological material (see below). Iodine staining is frequently used to visualize starch and glycogen even within tissues, however false positive signals are possible as these tests are not strictly highly specific for starch or glycogen, as other glucosyl residues containing polyand oligomers, e.g., maltodextrins, can interfere, and therefore, additional analyses are necessary for higher precision.

As an example, companies are selling starch kits (e.g., Megazyme Total Starch Assay Kit). These kits are in principle based on the enzymatic or chemical hydrolysis of starch, resulting in the exclusive formation of glucose monomers. The glucose is further enzymatically converted via glucose-6-phosphate to 6-phosphogluconolactone by hexokinase (EC 2.7.1.1) and glucose-6-phosphate dehydrogenase (EC 1.1.1.49), resulting also in a conversion of nicotinamide adenine dinucleotide phosphate $\left(\mathrm{NADP}^{+}\right)$ into the reduced form NADPH. The formation of NADPH is then spectroscopically measured (light absorbance at 334, 340, or $365 \mathrm{~nm}$ ). In addition, also NAD ${ }^{+}$converting glucose-6-phosphate dehydrogenases can be applied forming NADH. It should be mentioned that such quantification method measures total starch comprising both components amylopectin and amylose. Information about amylose and amylopectin proportion within starch is gained by iodine staining methods and/or combination with further fractionation methods (see Section 5).

\section{Analysis of Entire Starch Particles and Glycogen Molecules}

In contrast to glycogen, the water insoluble starch granules can be easily analyzed in terms of their morphology by various microscopic methods (structure level 1, Table 1). The observed starch morphologies are typically species- and tissue- specific. The size of the starch granules isolated from different species also varies widely from below $1 \mu \mathrm{m}$ up to several $100 \mu \mathrm{m}[45,46]$. For example, transitory starch granules are mostly in a range below $7 \mu \mathrm{m}$ having a flat, discoid, or slightly round shape [47-51]. Starch granules from different storage organs have a bigger variability in size and shape, e.g., potato (Solanum tuberosum L.) starch granules are spherical with up to $100 \mu \mathrm{m}$ in diameter. Maize starch granules are irregular-polyhedral shaped with a size range between 5 to $20 \mu \mathrm{m}$ [45]. Wheat and barley endosperm contain two different starch granule populations, with sizes between 10 and $40 \mu \mathrm{m}$ (A type) and below $10 \mu \mathrm{m}$ (B type) having a discoid and spherical granule shape, respectively [52-55]. For the sake of clarity, it is to mention, that here A and B-type starch particles are not related to A and B type allomorphs, thus to the inner starch structure. Moreover, for endosperm of rice and oat also compound starch granules were described [56-59].

The morphology of starch granules can be assessed by various microscopic methods. Traditional light microscopy techniques can give some information, e.g., the detection of the Maltese cross and hilum reveals the ordered inner structure of the starch [60-64]. Confocal microscopy is a powerful technique for morphology analysis of starch granules in situ [65-67]. Furthermore, the staining of starch granules with pseudo-Schiff propidium iodide allows fast and easy detection of starch granules in tissues [68,69].

Today, transmission (TEM) and scanning (SEM) electron microscopic methods are mainly used (Figure 2A-D). TEM allows the analysis of starch granules inside plastids, cells, and tissues following fixation and contrasting the ultra-thin slices [50,56]. However, the information obtained for the starch granules is always limited by the section of the cut. Consequently, only two-dimensional data are collected. 
Using multiple sections, three-dimensional data can also be obtained, although this requires increased effort. In addition, granule shrinking can occur due to dehydration of the tissues during preparation, resulting in an underestimation of the starch granules size. SEM is used for the analysis of isolated starch granules (structure level 1, Table 1) [16,45,70-72]. Starch granules are often coated in vacuum with a thin layer of gold but can also be used without any coating or pre-treatment [71,73]. In principle, SEM of starch granules may also allow the detection of modifications such as phosphorylation via the energy dispersive X-ray analysis (EDX detector) or wavelength dispersive X-ray analysis (WDX). Thus, the combination of SEM with EDX/WDX detection allows to gain information about internal structure at the structural level 2. These detectors monitor the characteristic energy and intensity of elements contained in the sample and therefore allow for the detection of, e.g., phosphor compounds. However, so far, such data have not been published for starch.

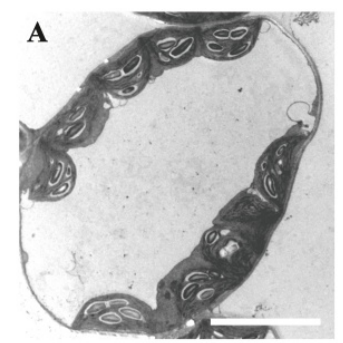

$\mathbf{E}$

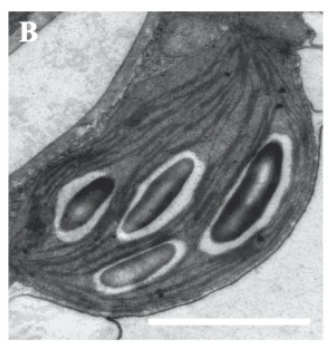

F。
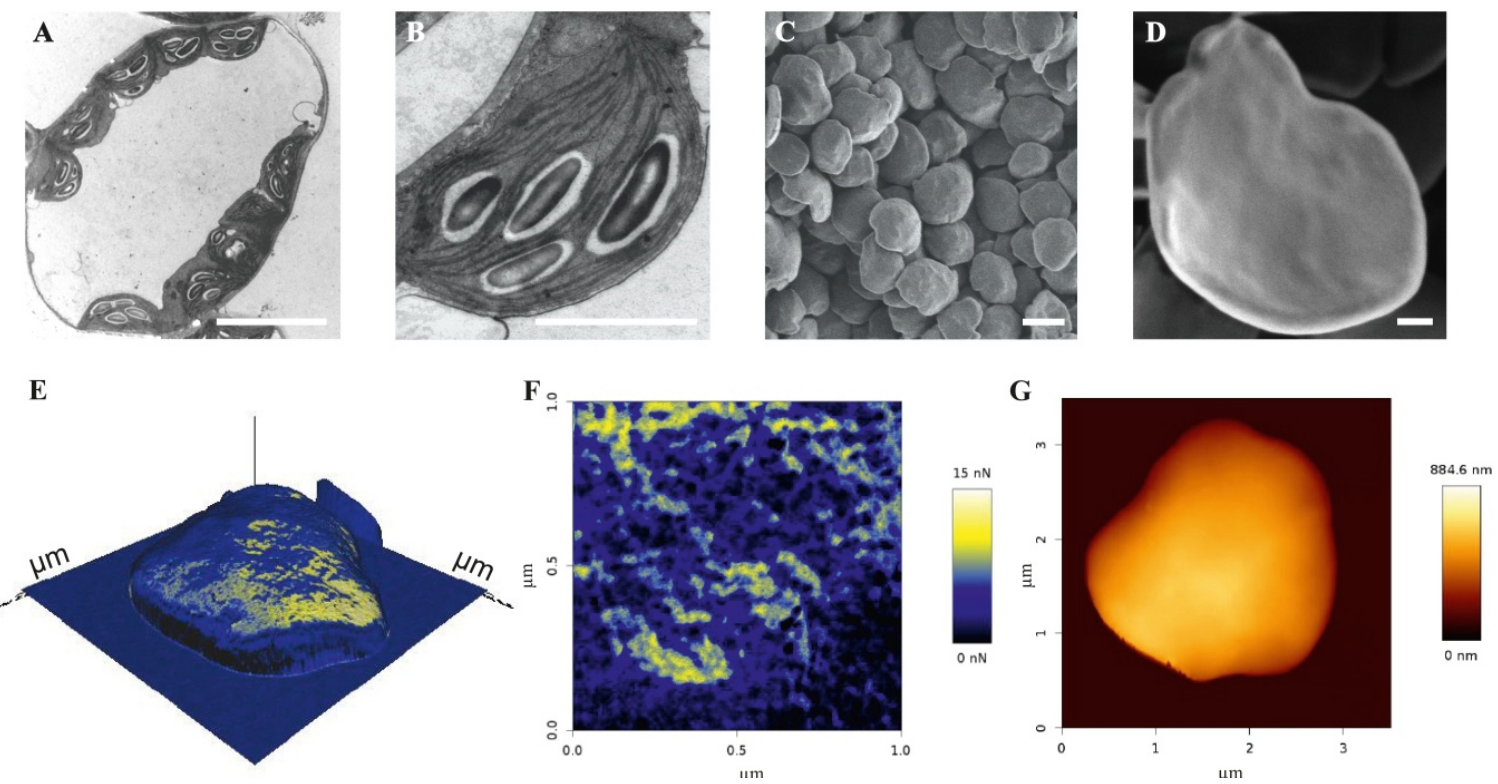

Figure 2. Microscopic analyses of leaf starch granules from Arabidopsis thaliana wild type Col-0 in situ and in vitro analyses. A and B: in situ analysis; Transition electron microscopy (TEM) of a mesophyll cell including chloroplast with starch granules (A) and of a chloroplast with starch granules (B). In vitro analysis; C and D: Scanning electron microscopy (SEM) of isolated native starch granules. The bars are equal to $10 \mu \mathrm{m}$ (A), $2 \mu \mathrm{m}$ (B), $1 \mu \mathrm{m}$ (C), and $200 \mathrm{~nm}$ (D). E-G: In vitro analysis; atomic force microscopy images. E. Overview scan in adhesion (retract) mode. F. Zoom in of the adhesion (retract) scan. G. Height measurement scan of the same starch granule.

Furthermore, inner structural information, such as the lamella architecture within the starch, can be obtained of intact polymers (structural level 2, Table 1) by various X-ray techniques, especially smalland wide-angle scattering (SAXS and WAXS, respectively; [74,75]) and X-ray diffraction (XRD; [72]). Atomic force microscopy (AFM) has also been applied to starch analysis [73,76-83]. AFM allows to determine the properties of starch surface structures, including starch modifications on the surface. However, due to the three-dimensional characteristics of starch granules and the resulting large altitude differences accompanied by the limitations of AFM in the z-axis, only parts of entire starch granules can be mostly analyzed (Figure 2E-G).

In addition to the morphological descriptions of starch granules, the sizes of starch granules are also of interest. Supplemental to the described microscopic methods that allow (especially by three- dimensional analyses) a relatively accurate determination of starch granule sizes and volumes (structural level 1, Table 1). Multisizer can be applied to get fast statistical information about population of granule sizes and volumes [16,84-90]. The electrical sensing zone method, used here, is based on the increase in electric resistance by particles in an electrical field passing an aperture or pore 
between two electrodes. Therefore, the electrical sensing zone method is unaffected by the particle color, shape, composition, or refractive index. Also flow cytometric analyses of starch granules have been reported [91-93].

As a result of microscopic methods, individual or multiple starch granules can be described, whereas the multisizer can give an overview of the size distribution of a population of starch granules. However, based on the measurement principle, the determined size of the starch granules is an approximation. In contrast to most microscopic methods the isolation of starch granules is strictly necessary for multisizer and SEM analyses. Therefore, the determined sizes of the starch granules must be critically reviewed in regard to the isolation procedure, especially considering, e.g., (partial) rupture of the starch granules and size-selective isolation. Similarly, the sizes of glycogen molecules can be directly determined, only following isolation, by separation techniques such as liquid chromatography and field flow fractionation. Coupling with multi angle laser light scattering allows for the most precise determination of the weight-average molecular weight of glycogen molecules [30,94-97]. However, also here, only a population of glycogen molecules can be described, and the accuracy is very sensitive to the isolation of glycogen.

In principle, nuclear magnetic resonance (NMR) can also be applied for starch analyses (structural level 2, Table 1). Thus, solid-phase NMR can be used for the analysis of entire starch granules [90,98-101]; however, in most cases so far, the starch is solubilized or further degraded prior to NMR analyses to allow analyses of covalent starch modification, such as phosphate esters $[72,75,98,99,102-108]$. Similarly, NMR analysis was applied to glycogen [105,109].

\section{Solubilization and Fractionation of Starch into Amylose and Amylopectin}

As out lined before, structural levels 3 and 4 (see Table 1) can only be analyzed following solubilization of the starch granules. In principle, various methods for solubilization exist.

When starch granules are heated in water, their semi-crystalline nature is gradually eliminated, resulting in structural breakdown and starch polymer dispersion in solution. This heat-induced phase transition from an ordered granular structure into a disordered state in water is known as gelatinization [110-113]. However, analyses of thermal properties allow the comparison of starches and indications for alterations in the internal starch structure, but they will not allow determination of the inner starch structure in more detail.

In addition to exclusive heat treatment of the isolated starch, additional procedures exist. All these methods can be sub-grouped into enzymatic or chemical treatments. The latter are mostly connected with a heat treatment. In connection with the further applied analytical techniques, several solvents such as dimethyl sulfoxide (DMSO) [106,114-120]; $\mathrm{NaOH}, \mathrm{KOH}$, urea/ $\mathrm{NaOH}$ [121], and $\mathrm{ZnCl}_{2}$ [122] are used. Treatment with $\mathrm{KOH}$ or $\mathrm{NaOH}$ is the most common, as fewer limitations occur in down-stream processing.

Treatment with starch-degrading enzymes is also possible but results in a massive loss of structural information of structure levels 3 and 4 depending on the enzyme used. Therefore, it is important to distinguish between the use of enzymes for solubilization and the application of enzymes for structural analysis. The latter is of interest for both starch and glycogen. As both glucans only consist of $\alpha 1,4$ and $\alpha 1,6$ linkages, only enzymes that act on these linkages can be applied (see below).

Independent of the solubilization method, the time of treatment is critical as partial or total solubilization can be achieved.

Furthermore, following solubilization, isolation of the two polyglucans types, amylopectin and amylose is also possible. Several techniques are commonly in use to fractionate starch into its components, amylopectin and amylose, based on their different physicochemical properties (e.g., solubility, diffusion, hydrodynamic, and complexing properties due to degree of branching, molecular weight). Mandatory for the separation of both types of polyglucans is the solubilization of purified/extracted starch leading to the dissolution and loss of crystallinity. Storage starches are commonly dissolved using organic solvents (DMSO) or alkaline solutions $(\mathrm{NaOH}, \mathrm{KOH})$, often together with heating. In addition, use 
of physical methods such as autoclaving or heating via microwaves leads to swelling of the granules and destruction of the crystalline structure in aqueous solution [123-125]. Heating of starch in aqueous solution below the melting point of amylopectin (solubilization of amylopectin is avoided) leads to leaching of amylose [126-129]. Amylopectin is pelleted by centrifugation, while leached amylose remains in the supernatant. Efficiency of the leaching procedure is strongly dependent on the starch concentration, temperature, heating and cooling rate, and duration [130]. Moreover, the procedure takes several hours or days. In addition, an increase in fraction purity and yield is achieved when subsequently the leached amylose is precipitated [130-132].

The complex formation of amylose with hydrophobic substances, such as n-butanol, thymol, or a mixture of n-butanol and isoamyl alcohol, leads to precipitation of amylose that can be separated from amylopectin by centrifugation [133-138]. Amylopectin in the supernatant is recovered by ethanol or methanol precipitation $[125,134,135,139]$. Repetitive dissolution and precipitation steps are applied to obtain polysaccharide fractions $[139,140]$.

The separation of amylopectin and amylose with concanavalin A is based on the ability of the lectin to bind non-reducing ends of glucans [141-144]. As the concanavalin A homotetramer has four binding sites, amylopectin molecules precipitate very efficiently, and amylose resides in the supernatant after centrifugation [144-146]. Megazyme International Ltd. (Wicklow, Ireland) offers a kit to separate amylose and amylopectin to measure their contents. The concanavalin A-based method is applied to a wide variety of starches from different origins such as cassava [147], common cattail [148], kiwi [149], potato [147], rice [131], tomato fruit [150], quinoa [151], and yam bean [152].

The different molar masses of amylose and amylopectin allow for separation via chromatographic methods such as size exclusion chromatography (SEC) [153]. SEC is used for the quantification of each component within starches and as a preparative method for further analysis [152,154-157].

A widely used technique to measure amylose contents in starch samples or starch fractions is based on the ability of amylose and amylopectin to bind iodine with different capacities. Binding of iodine with amylose leads to the formation of deep-blue complexes, while binding with amylopectin results in a reddish-brown color formation. Maximal absorbance of iodine bound to amylopectin is between $500-560 \mathrm{~nm}$, and that for iodine bound to amylose is above $580 \mathrm{~nm}[158,159]$. Absorption of the amylose-iodine complex is recorded spectrophotometrically at defined wavelength maxima between 600 and $680 \mathrm{~nm}$ for different starch samples (e.g., for $600 \mathrm{~nm}$, [160-162]; for $620 \mathrm{~nm}$ [20,163-168]; for $625 \mathrm{~nm}$ [169,170]; for 635nm [23,125,171,172]; for $640 \mathrm{~nm}$ [19]). Absorbance of $1 \mathrm{mg}$ starch in $100 \mathrm{~mL}$ with a defined concentration of iodine and potassium iodide at $680 \mathrm{~nm}$ is usually referred to as the "blue value" [173-178]. Calibration curves at defined wavelengths with defined starch amounts are used to calculate amylose contents within starch samples [163,164,166,170,171,179,180]. Recording of wavelength spectra in a range between $270-900 \mathrm{~nm}$ or recording of absorbances at two to three defined wavelengths are also applied to analysis of the maximum absorbance and sufficiency of iodine concentration for different starch samples and for the analysis of amylopectin and amylose, respectively $[125,160,167,181]$. Iodine's affinity to amylose can also be measured by potentiometric iodine titration $[111,144,155,169,182]$ and by amperometric iodine titration $[134,170,177,183]$.

It should be noted that complexing of amylose with lipids influences both iodine binding capacity and the butanol precipitation procedure. Treatment and precipitation of solubilized starch with propanol [184], ethanol [171], or methanol [164,179,180] defats starch prior to further fractionation or content measurements. Thus, pre-treatment of unfractionated starch samples with alcohols has become established for estimation of apparent amylose contents by iodometric methods $[111,171,185,186]$. Moreover, some starches containing amylopectin with long and extra-long glucan chains ( $>100$ glucosyl residues) reveal higher iodine binding values and can lead to overestimation of amylose contents within starch samples [187-190]. This can be overcome by fractionation of starch and separate measurements of starch components to consider the impact of amylopectin component. 


\section{Enzymatic Treatments of Starch and Glycogen}

To get further intra molecular structural information (structure level 4, Table 1) it is necessary to specific fragment the polymers in oligoglucans prior to further separations (see below). Starch and glycogen contain exactly the same inter-glycosidic linkages, $\alpha 1,4$ and $\alpha 1,6$. Consequently, the same enzymes can be applied for the structural analysis of both polysaccharides.

Most common is the use of amylases. $\alpha$-Amylases (EC 3.2.1.1) are endo-hydrolytic enzymes that cleave inner $\alpha 1,4$ glycosidic linkages and consequently release maltose, maltotriose, or branched oligosaccharides. As the enzyme is unable to cleave terminal $\alpha 1,4$ linkages, the release of glucose is not observed. $\alpha$-Amylases comprise a wide collection of enzymes from all biological classes, such as animals, plants, fungi, and bacteria. These $\alpha$-amylases have different product specificities. However, all $\alpha$-amylases form a product that has the $\alpha$-configuration at the anomeric carbon. $\beta$-Amylases (EC 3.2.1.2) also cleave $\alpha 1,4$ glycosidic linkages but these enzymes are exo-hydrolases and hydrolyze glucans by a mechanism that create inversion of the configuration at the anomeric carbon, releasing $\beta$-maltose from the non-reducing end of a glucan chain. A third group of amylases contains the $\gamma$-amylases or amyloglucosidases (EC 3.2.1.3). These enzymes are also exo-hydrolases, cleaving $\alpha 1,4$ glycosidic linkages but releasing $\beta$-glucose from the non-reducing end of a glucan chain.

In contrast, isoamylases (EC 3.2.1.68) cleave $\alpha 1,6$ glycosidic linkages and therefore release linear chains from both glycogen and starch.

All the different amylases are widespread, and thus, there are enzymes with various temperature and $\mathrm{pH}$ optima available. Bacterial amylases have been reported that have very high temperature stability and an optimal temperature of activity around $100^{\circ} \mathrm{C}$ (e.g., Wu et al., 2018).

$\alpha 1,6$ glycosidic linkages can also be cleaved by glycogen-debranching enzymes mediating an indirect debranching. In a strict sense, these monomeric enzymes, found in animals and fungi, possess two enzymatic activities coded in their single polypeptide chains. One enzymatic activity is an $\alpha 1,4$ glucanotransferase (EC 2.4.1.25) that transfers a linear $\alpha 1,4$ glucan chain except the single glucosyl residue attached via $\alpha 1,6$ glycosidic bond. The second enzymatic activity is an $\alpha 1,6$ glycosidase (EC 3.2.1.33) that releases the glucosyl residue as free glucose. Despite the amylases that can be used for structural analysis of starch and glycogen, glycogen-debranching enzymes are rather unfavorable, as the resulting product is difficult to interpret. However, enzymes can also be used for total degradation of the polyglucans to glucose, as performed in the course of determining the amounts of the storage glucans [191,192]. Therefore, amyloglucosidases or mixtures of several enzymes are used.

In contrast, for the determination of the chain length distribution pattern (CLD, see below) for glycogen and starch, the selective hydrolysis of $\alpha 1,6$ glycosidic linkages by a direct debranching enzyme, e.g., isoamylase is necessary. Also sequential hydrolyses in combination with phosphorylase a and/or $\beta$-amylases and/or $\alpha$-amylases to get different kinds of limit-dextrins are in use to get information about structural organization of branching points and glucan chain lengths [193].

Interestingly, enzymatic treatment is also used for native starch granules that have not been solubilized. Here, specific properties of the starch granule surface can be analyzed, such as the surface near glucan chains [16,71]. Moreover, these analyses can also include various enzymes that can elongate existing glucan chains at the starch granule surface, such as starch synthases and glucan phosphorylases $[16,71,194,195]$. From these experiments, information about the starch surface can be found and different starches can be compared. In principle, two types of analyses can be distinguished. In the first, enzymes are used, and their catalytic action is determined, e.g., the release of glucan chains from the starch granule surface or the elongation of the surface near glucan chains. The sensitivity can be increased by including radioactive labels $[13,16,71,194-196]$. In a second type, only the binding of the enzymes at the starch granule surface is followed. This allows the user to collect information about starch surface properties when the binding characteristics of the enzymes are known (see below).

In similar experiments analyzing the native starch granule surface, enzymes can be included that do not affect $\alpha 1,4$ or $\alpha 1,6$ glycosidic linkages, such as glucan water dikinase (GWD; [71,104,194,197]), or phosphoglucan water dikinase (PWD; [104,194,198]). GWD and PWD are involved in the phosphorylation/ 
dephosphorylation cycle of the transitory starch degradation $[199,200]$. Both enzymes introduce phosphate groups, via a dikinase reaction, into amylopectin. GWD phosphorylates the $\mathrm{C} 6-\mathrm{OH}$, whereas PWD phosphorylates the C3-OH of a glucosyl residue of amylopectin (for review see $[200,201]$ ). Both phosphorylations are the only known naturally occurring covalent modifications of starch. Thus, the binding and the action of these enzymes at the starch granule surface also allow for the determination of starch properties and the differentiation of starches [71,194]. Furthermore, the use of enzymes either in combination or sequentially helps to increase the knowledge about starch surface properties [71,194].

\section{Methods for the Characterization of Glucans Released from Starch and Glycogen}

Solubilized starch and glycogen as well as released glucans following enzymatic or chemical treatment can be analyzed by various methods to determine the molar mass of the molecules as well as the size distribution and thus information of structural level 3 and 4 (Table 1) can be collected.

In some cases, a fast separation of released glucans and remaining insoluble starch granules or large remaining parts of starch and glycogen can be achieved by simple centrifugation or the usage of microfilter units. In addition, precipitation of glucans is common using increasing concentrations of methanol, ethanol or salts as described above.

Two often-used techniques are size exclusion chromatography, as mentioned previously $[95,97$, $117,118,202-214]$ and field flow fractionation, which allow the separation of small oligoglucans up to polyglucans $[94,206,215-217]$. The advantage of the latter is the lack of potential glucan-matrix interactions that can result in unclean separation and false correlation [218,219]. It should be noted that these techniques are also used for entire amylose, amylopectin, and glycogen molecules $[97,204$, 206,220-224].

Today, several faster and more sensible modern methods exist. Most common is the analysis of enzymatically processed starch and glycogen products with capillary electrophoreses (CE) or high performance anion exchange chromatography (HPAEC). The maximum degree of polymerization (DP) limit for both methods is approximately 70 . Both methods are differentially compatible with the detection of glucans following separation. In CE, the glucans are mostly detected by fluorescence (laser induced fluorescence; LIF), and thus, coupling of the carbohydrates via the reducing end is necessary with a fluorescent dye (e.g., APTS, ANTS). In contrast, no derivatization of the glucans is needed following separation of the glucans by HPAEC; instead, amperometric detection, especially pulsed amperometric detection (PAD) is common. A typical CLD profile of debranched transitory starch from Arabidopsis thaliana displays a polymodal distribution that is diminished in mutant plants lacking the major soluble starch synthase isoform (Figure 3) [51,225]. Absolute quantification of glucan chains separated and detected by HPAEC-PAD is limited as suitable standards are missing and sensitivity of PAD signal is decreasing with increasing glucan chain lengths. However, amperometric detection is fast and cost-effective and gives reliable information about different kinds of wild type and mutant starches [51,187,225-230]. However, the obtained CLD profiles, following enzymatic debranching (e.g., by isoamylase) do not allow to explain the branching pattern within the molecule, as it only gives an average of the included glucan chains.

Smaller glucans released from starch or glycogen can also be analyzed by mass spectrometry, mostly using matrix assistant laser desorption and ionization (MALDI) mass spectrometry with 2,5-Dihydroxybenzoic acid (DHB) as matrix [207,231,232]. MALDI mass spectrometry is in principle also possible in a high-throughput process using spotting devices; however, the collected data are mostly semi-quantitative, and therefore, it is comparatively less effective than CE-LIF. However, for analysis of in vitro or in vivo modifications of starches, starch- and glycogen-like molecules and glycogen, MALDI mass spectrometry is the method of choice $[197,233,234]$. In addition to the detection of entire phosphoglucans, the internal position of the phosphate group can be determined. This comprises the phosphorylated carbon of a glucosyl residue (C6 or $\mathrm{C} 3-\mathrm{OH}$ group) as well as the position of glucosyl residue within in the glucan chain. 


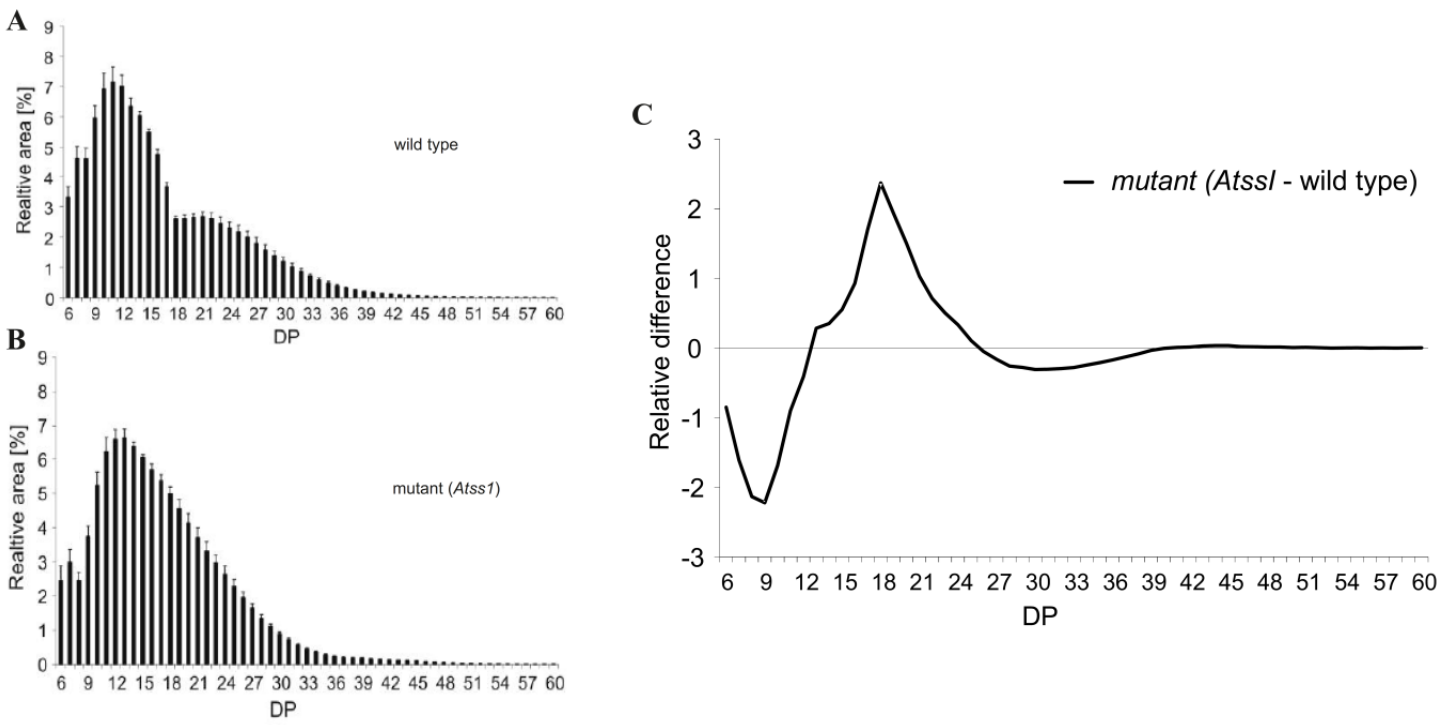

Figure 3. Typical chain length distribution (CLD) profiles of starches from Arabidopsis thaliana analyzed by HPAEC-PAD. (A) and (B) CLD profiles from wild type and Atss1 mutant. Plants were grown in a $12 \mathrm{~h}$ light/12 $\mathrm{h}$ dark cycle and leaves were harvested at the end of the light period. The isolated starches were digested with isoamylase to degrade the $\alpha 1,6$ linked branching points within the amylopectin. (C) Difference plots were obtained by subtraction CLD profile of wild type from mutant CLD. Differences of mean values are presented. DP-degree of polymerization.

\section{Protein Binding Analyses}

In addition to the carbohydrate-related analyses of starch and glycogen, protein analytics of both carbon stores can also be performed. For starch and glycogen, binding and integration of proteins have been reported. Thus, for glycogen, the binding of glycogenin, glycogen synthase, glycogen phosphorylase, glycogen debranching enzyme, laforin as well as kinases and phosphatases were reported [235-238]. In the case of starch, at least two alternatives can be distinguished: The binding of proteins at the starch granule surface or the integration of proteins inside the granule. Several examples and proteomic analyses exist for both [239-245]. The most prominent is the integration of the granule-bound starch synthases (GBBS), thought to be responsible for the generation of amylose [9,246-248], into starch granules from several species (amaranth [249]; barley [250,251]; maize [252,253]; pea [25,254]; potato $[159,255]$; rice [256]; and wheat $[257,258]$ ). Here, the proteins cannot be washed away under any conditions. The proteins can only be released if the starch is solubilized or chemically or enzymatically degraded. Therefore, it is evident that these proteins are not related to contamination or artefacts. The opposite is the case for proteins bound to the starch surface. In addition to several identified proteins related to starch metabolism, e.g., GWD [12,13,241], PWD [13,241], PHS1/PHO1 [239-243], ESV1 [194,241,259], FLO6 [260], PTST1 [241,261], LESV [241,259], LSV2 [241], SEX4 [241], debranching enzyme isoforms [239-241,245], starch synthase isoforms [21,239,241-243,262-264], starch branching enzyme isoforms [21,239,241-243,262,264-268], and proteins not directly involved in starch metabolism were also reported $[21,239,241,245]$.

To date, it is unclear whether some integrated or bound proteins are also important for the overall structural properties of the starch granules.

Besides analysis of catalytic actions of enzymes at the starch granule surface and its resulting glucan products (see Section 6) also the binding of proteins or enzymes to native starch granules allows the collection of further information about the starch structural characteristics in vitro. Such experiments can also be extended by pre-treatment of the starch via, for instance, hydrolytic digestion by enzymes [66]. Moreover, protein carbohydrate analysis with soluble polyglucans (e.g., solubilized starches and starch fractions) typical methods, such as NMR, isothermal titration calorimetry, fluorescence 
spectroscopy, surface plasmon resonance, micro scale thermophoresis, and biolayer interferometry can be applied. Binding of proteins to starch granules in vivo can be analyzed by using transgenic plants expressing proteins labelled with a fluorescent group, such as e.g., GFP, YFP, or mCherry [261,269-271]. Fluorescence microscopy allows the determination of the distribution of the proteins within the plastids and at the starch granule (surface). Thus, a clustered distribution can be easily distinguished from a randomly even allocation of the binding protein. Furthermore, by combining of several differently labelled proteins, co-localization can be monitored. However, it should be mentioned, that due to the altered (over)expression of these proteins within plants a generation of artefacts must be considered.

\section{Conclusions and Future Perspectives}

Over the past few decades various carbohydrate analysis techniques have been established, and subsequently, the starch and glycogen fields have benefitted. Thus, more and more detailed information about starch and glycogen has been obtained. A covalent modification, the phosphorylation of glycogen and starch, was identified, and various mutants with different starch morphologies, altered inner structures, and modified surface properties have been reported.

However, many open questions remain. For example, for both starch and glycogen, covalent modification by phosphorylation has been detected. However, to date, the molecular order of this phosphorylation event is unclear. Thus, e.g., the exact position of the phosphorylation, i.e., the glucosyl residue in the glucan chain, the distance to branching points, the distance between two phosphorylation events, and the physical or chemical background are obscure. Similar to the modification of starch and glycogen, the order at the surface of both polyglucans is far from being resolved. More and more results point to specific characteristics of the surface that influence the interaction with proteins, and thus, the changing surface is critical for biological function. Thus, for biological and biochemical analyses, the surface is the focus of the research, as almost all interactions with proteins occur here. This includes the synthesis as well as the degradation of new glycosidic linkages. Furthermore, the results of the action of enzymes and proteins during synthesis at the surface presuppose the created inner structure. In addition, both the actions of enzymes and proteins during synthesis and degradation presuppose the available surface. In this dynamic molecular world, the currently available methods are limited. This limitation comprises, a time component as well as an individual component. Thus, for many analyses, at least the isolation of glycogen or starch is needed, which reduces the time resolution of possible analyses. Additionally, it can also alter parameters of the analyte. Furthermore, as most of the analyses cannot be performed with a single starch or glycogen molecule, due to the low amount, almost all data to date are averages, limiting your insight. Depending on the analytic question and method, this averaging can include different physiological or metabolic states of the same cell but can also include analytes from different cells, tissues or even organs. Thus, especially small alterations can be underestimated.

Similarly, in regard to the analyses of the inner structure, nearly no individual starch or glycogen molecule has been analyzed to date, limiting our knowledge about possible natural variance. Interestingly, an analysis of a single giant starch granule from orchid was reported [272].

However, analyze of characteristics such as the size and shape and the resulting properties for applications when huge amounts of the polyglucans are necessary, especially starch, can be more accurate, faster, and obtained more cheaply. Therefore, analytic needs differ largely among the various scientific and industrial sectors. However, gaining more insight into individual molecular structures will also be helpful for crude industrial applications. Furthermore, in computational science, particularly modelling, it has become more and more important to develop new ideas about the exact properties of starch and glycogen.

Author Contributions: All authors together have written this review. All authors have read and agreed to the published version of the manuscript.

Funding: This research was founded by Deutsche Forschungsgemeinschaft (DFG) to Joerg Fettke grant number FE1030/5-1 and DFG FE1030/6-1. Slawomir Orzechowski was founded be SGGW grant number S00125/2020. 
Acknowledgments: We thank Martin Steup for the initial idea for this review, Daniel Schäfer for the AFM pictures, and Julia Compart for help during the preparation of this manuscript.

Conflicts of Interest: The authors declare no conflict of interest.

\section{References}

1. Bräsen, C.; Esser, D.; Rauch, B.; Siebers, B. Carbohydrate Metabolism in Archaea: Current Insights into Unusual Enzymes and Pathways and Their Regulation. Microbiol. Mol. Biol. Rev. MMBR 2014, 78, 89-175. [CrossRef] [PubMed]

2. Wilson, W.A.; Roach, P.J.; Montero, M.; Baroja-Fernández, E.; Muñoz, F.J.; Eydallin, G.; Viale, A.M.; Pozueta-Romero, J. Regulation of glycogen metabolism in yeast and bacteria. FEMS Microbiol. Rev. 2010, 34, 952-985. [CrossRef] [PubMed]

3. Buléon, A.; Gallant, D.J.; Bouchet, B.; Mouille, G.; D’Hulst, C.; Kossmann, J.; Ball, S. Starches from A to C (Chlamydomonas reinhardtii as a Model Microbial System to Investigate the Biosynthesis of the Plant Amylopectin Crystal). Plant Physiol. 1997, 115, 949-957. [CrossRef] [PubMed]

4. He, W.; Wei, C. Progress in C-type starches from different plant sources. Food Hydrocoll. 2017, 73, $162-175$. [CrossRef]

5. Genkina, N.K.; Wikman, J.; Bertoft, E.; Yuryev, V.P. Effects of Structural Imperfection on Gelatinization Characteristics of Amylopectin Starches with A- and B-Type Crystallinity. Biomacromolecules 2007, 8, 2329-2335. [CrossRef]

6. Imberty, A.; Buléon, A.; Tran, V.; Péerez, S. Recent Advances in Knowledge of Starch Structure. Starch-Stärke 1991, 43, 375-384. [CrossRef]

7. Buléon, A.; Colonna, P.; Planchot, V.; Ball, S. Starch granules: Structure and biosynthesis. Int. J. Biol. Macromol. 1998, 23, 85-112. [CrossRef]

8. Jane, J.; Xu, A.; Radosavljevic, M.; Seib, P.A. Location of Amylose in Normal Starch Granules. I. Susceptibility of Amylose and Amylopectin to Cross-Linking Reagents. Cereal Chem. 1992, 69, 405-409.

9. Ball, S.G.; van de Wal, M.H.B.J.; Visser, R.G.F. Progress in understanding the biosynthesis of amylose. Trends Plant Sci. 1998, 3, 462-467. [CrossRef]

10. Zeeman, S.C.; Smith, S.M.; Smith, A.M. The Priming of Amylose Synthesis in Arabidopsis Leaves. Plant Physiol. 2002, 128, 1069-1076. [CrossRef]

11. Pérez, S.; Bertoft, E. The molecular structures of starch components and their contribution to the architecture of starch granules: A comprehensive review. Starch-Stärke 2010, 62, 389-420. [CrossRef]

12. Ritte, G.; Lorberth, R.; Steup, M. Reversible binding of the starch-related R1 protein to the surface of transitory starch granules. Plant J. 2000, 21, 387-391. [CrossRef] [PubMed]

13. Kötting, O.; Pusch, K.; Tiessen, A.; Geigenberger, P.; Steup, M.; Ritte, G. Identification of a Novel Enzyme Required for Starch Metabolism in Arabidopsis Leaves. The Phosphoglucan, Water Dikinase. Plant Physiol. 2005, 137, 242-252. [CrossRef] [PubMed]

14. Malinova, I.; Alseekh, S.; Feil, R.; Fernie, A.R.; Baumann, O.; Schöttler, M.A.; Lunn, J.E.; Fettke, J. Starch synthase 4 and plastidal phosphorylase differentially affect starch granule number and morphology. Plant Physiol. 2017. [CrossRef]

15. Hostettler, C.; Kölling, K.; Santelia, D.; Streb, S.; Kötting, O.; Zeeman, S.C. Analysis of Starch Metabolism in Chloroplasts. In Chloroplast Research in Arabidopsis: Methods and Protocols, Volume II; Jarvis, R.P., Ed.; Humana Press: Totowa, NJ, USA, 2011; pp. 387-410. [CrossRef]

16. Fettke, J.; Leifels, L.; Brust, H.; Herbst, K.; Steup, M. Two carbon fluxes to reserve starch in potato (Solanum tuberosum L.) tuber cells are closely interconnected but differently modulated by temperature. J. Exp. Bot. 2012, 63, 3011-3029. [CrossRef]

17. Wang, K.; Hasjim, J.; Wu, A.C.; Henry, R.J.; Gilbert, R.G. Variation in Amylose Fine Structure of Starches from Different Botanical Sources. J. Agric. Food Chem. 2014, 62, 4443-4453. [CrossRef]

18. Correia, P.R.; Beirão-da-Costa, M.L. Chestnut and acorn starch properties affected by isolation methods. Starch-Stärke 2010, 62, 421-428. [CrossRef]

19. Syahariza, Z.A.; Li, E.; Hasjim, J. Extraction and dissolution of starch from rice and sorghum grains for accurate structural analysis. Carbohydr. Polym. 2010, 82, 14-20. [CrossRef] 
20. Juliano, B.O.; Perez, C.M.; Blakeney, A.B.; Castillo, T.; Kongseree, N.; Laignelet, B.; Lapis, E.T.; Murty, V.V.S.; Paule, C.M.; Webb, B.D. International Cooperative Testing on the Amylose Content of Milled Rice. Starch-Stärke 1981, 33, 157-162. [CrossRef]

21. Borén, M.; Larsson, H.; Falk, A.; Jansson, C. The barley starch granule proteome-internalized granule polypeptides of the mature endosperm. Plant Sci. 2004, 166, 617-626. [CrossRef]

22. Correia, P.R.; Beirão-da-Costa, M.L. Starch isolation from chestnut and acorn flours through alkaline and enzymatic methods. Food Bioprod. Process. 2011, 90,309-316. [CrossRef]

23. Sakshi, S.; Singh, S.; Riar, C.S. Isolation of starches from different tubers and study of their physicochemical, thermal, rheological and morphological characteristics. Starch-Stärke 2016, 68, 160-168. [CrossRef]

24. Ritte, G.; Eckermann, N.; Haebel, S.; Lorberth, R.; Steup, M. Compartmentation of the Starch-Related R1 Protein in Higher Plants. Starch-Stärke 2000, 52, 179-185. [CrossRef]

25. Tomlinson, K.L.; Lloyd, J.R.; Smith, A.M. Importance of isoforms of starch-branching enzyme in determining the structure of starch in pea leaves. Plant J. 1997, 11, 31-43. [CrossRef]

26. Cairns, A.J.; Begley, P.; Sims, I.M. The structure of starch from seeds and leaves of the fructan-accumulating ryegrass, Lolium temulentum L. J. Plant Physiol. 2002, 159, 221-230. [CrossRef]

27. Tagliabracci, V.S.; Turnbull, J.; Wang, W.; Girard, J.-M.; Zhao, X.; Skurat, A.V.; Delgado-Escueta, A.V.; Minassian, B.A.; DePaoli-Roach, A.A.; Roach, P.J. Laforin is a glycogen phosphatase, deficiency of which leads to elevated phosphorylation of glycogen in vivo. Proc. Natl. Acad. Sci. USA 2007, 104, 19262-19266. [CrossRef]

28. Lomako, J.; Lomako, W.M.; Whelan, W.J.; Marchase, R.B. Glycogen contains phosphodiester groups that can be introduced by UDPglucose:glycogen glucose 1-phosphotransferase. FEBS Lett. 1993, 329, $263-267$. [CrossRef]

29. Ryu, J.-H.; Drain, J.; Kim, J.H.; McGee, S.; Gray-Weale, A.; Waddington, L.; Parker, G.J.; Hargreaves, M.; Yoo, S.-H.; Stapleton, D. Comparative structural analyses of purified glycogen particles from rat liver, human skeletal muscle and commercial preparations. Int. J. Biol. Macromol. 2009, 45, 478-482. [CrossRef]

30. Sullivan, M.A.; O'Connor, M.J.; Umana, F.; Roura, E.; Jack, K.; Stapleton, D.I.; Gilbert, R.G. Molecular Insights into Glycogen $\alpha$-Particle Formation. Biomacromolecules 2012, 13, 3805-3813. [CrossRef]

31. Tan, X.; Sullivan, M.A.; Gao, F.; Li, S.; Schulz, B.L.; Gilbert, R.G. A new non-degradative method to purify glycogen. Carbohydr. Polym. 2016, 147, 165-170. [CrossRef]

32. Welkie, D.G.; Lee, B.-H.; Sherman, L.A. Altering the Structure of Carbohydrate Storage Granules in the Cyanobacterium Synechocystis sp. Strain PCC 6803 through Branching-Enzyme Truncations. J. Bacteriol. 2016, 198, 701-710. [CrossRef]

33. Park, J.-T.; Shim, J.-H.; Tran, P.L.; Hong, I.-H.; Yong, H.-U.; Oktavina, E.F.; Nguyen, H.D.; Kim, J.-W.; Lee, T.S.; Park, S.-H.; et al. Role of Maltose Enzymes in Glycogen Synthesis by Escherichia coli. J. Bacteriol. 2011, 193, 2517-2526. [CrossRef]

34. Yokoi, S.; Austin, J.; Witmer, F.; Sakai, M. Studies in Myoclonus Epilepsy (Lafora Body Form): I. Isolation and Preliminary Characterization of Lafora Bodies in Two Cases. Arch. Neurol. 1968, 19, 15-33. [CrossRef] [PubMed]

35. Dauvillée, D.; Colleoni, C.; Mouille, G.; Buléon, A.; Gallant, D.J.; Bouchet, B.; Morell, M.K.; d'Hulst, C.; Myers, A.M.; Ball, S.G. Two Loci Control Phytoglycogen Production in the Monocellular Green Alga Chlamydomonas reinhardtii. Plant Physiol. 2001, 125, 1710-1722. [CrossRef] [PubMed]

36. Zeeman, S.C.; Umemoto, T.; Lue, W.-L.; Au-Yeung, P.; Martin, C.; Smith, A.M.; Chen, J. A Mutant of Arabidopsis Lacking a Chloroplastic Isoamylase Accumulates Both Starch and Phytoglycogen. Plant Cell Online 1998, 10, 1699-1712. [CrossRef] [PubMed]

37. Kubo, A.; Colleoni, C.; Dinges, J.R.; Lin, Q.; Lappe, R.R.; Rivenbark, J.G.; Meyer, A.J.; Ball, S.G.; James, M.G.; Hennen-Bierwagen, T.A.; et al. Functions of Heteromeric and Homomeric Isoamylase-Type Starch-Debranching Enzymes in Developing Maize Endosperm. Plant Physiol. 2010, 153, 956-969. [CrossRef]

38. Burton, R.A.; Jenner, H.; Carrangis, L.; Fahy, B.; Fincher, G.B.; Hylton, C.; Laurie, D.A.; Parker, M.; Waite, D.; Van Wegen, S.; et al. Starch granule initiation and growth are altered in barley mutants that lack isoamylase activity. Plant J. 2002, 31, 97-112. [CrossRef]

39. Sestili, F.; Sparla, F.; Botticella, E.; Janni, M.; D'Ovidio, R.; Falini, G.; Marri, L.; Cuesta-Seijo, J.A.; Moscatello, S.; Battistelli, A.; et al. The down-regulation of the genes encoding Isoamylase 1 alters the starch composition of the durum wheat grain. Plant Sci. 2016, 252, 230-238. [CrossRef] 
40. Wattebled, F.; Dong, Y.; Dumez, S.; Delvalle, D.; Planchot, V.; Berbezy, P.; Vyas, D.; Colonna, P.; Chatterjee, M.; Ball, S.; et al. Mutants of Arabidopsis Lacking a Chloroplastic Isoamylase Accumulate Phytoglycogen and an Abnormal Form of Amylopectin. Plant Physiol. 2005, 138, 184-195. [CrossRef]

41. Delatte, T.; Trevisan, M.; Parker, M.L.; Zeeman, S.C. Arabidopsis mutants Atisa1 and Atisa2 have identical phenotypes and lack the same multimeric isoamylase, which influences the branch point distribution of amylopectin during starch synthesis. Plant J. 2005, 41, 815-830. [CrossRef]

42. Powell, P.O.; Sullivan, M.A.; Sweedman, M.C.; Stapleton, D.I.; Hasjim, J.; Gilbert, R.G. Extraction, isolation and characterisation of phytoglycogen from su-1 maize leaves and grain. Carbohydr. Polym. 2014, 101, 423-431. [CrossRef] [PubMed]

43. Lin, Q.; Huang, B.; Zhang, M.; Zhang, X.; Rivenbark, J.; Lappe, R.L.; James, M.G.; Myers, A.M.; Hennen-Bierwagen, T.A. Functional Interactions between Starch Synthase III and Isoamylase-Type Starch-Debranching Enzyme in Maize Endosperm. Plant Physiol. 2012, 158, 679-692. [CrossRef] [PubMed]

44. Lu, K.-J.; Streb, S.; Meier, F.; Pfister, B.; Zeeman, S.C. Molecular Genetic Analysis of Glucan Branching Enzymes from Plants and Bacteria in Arabidopsis Reveals Marked Differences in Their Functions and Capacity to Mediate Starch Granule Formation. Plant Physiol. 2015, 169, 1638-1655. [CrossRef]

45. Jane, J.-L.; Kasemsuwan, T.; Leas, S.; Zobel, H.; Robyt, J.F. Anthology of Starch Granule Morphology by Scanning Electron Microscopy. Starch-Stärke 1994, 46, 121-129. [CrossRef]

46. Hoover, R. Composition, molecular structure, and physicochemical properties of tuber and root starches: A review. Carbohydr. Polym. 2001, 45, 253-267. [CrossRef]

47. Grange, R.I.; Hammond, J.B.W.; Andrews, J. Characteristics of Starch Grains Isolated from Mature Pepper Leaves Grown under Different Irradiances and Daylengths. J. Exp. Bot. 1989, 40, 1045-1052. [CrossRef]

48. Yu, S.; Zhang, F.; Li, C.; Gilbert, R.G. Molecular structural differences between maize leaf and endosperm starches. Carbohydr. Polym. 2017, 161, 10-15. [CrossRef]

49. Santacruz, S.; Koch, K.; Andersson, R.; Åman, P. Characterization of Potato Leaf Starch. J. Agric. Food Chem. 2004, 52, 1985-1989. [CrossRef]

50. Malinova, I.; Mahlow, S.; Alseekh, S.; Orawetz, T.; Fernie, A.R.; Baumann, O.; Steup, M.; Fettke, J. Double Knockout Mutants of Arabidopsis Grown under Normal Conditions Reveal that the Plastidial Phosphorylase Isozyme Participates in Transitory Starch Metabolism. Plant Physiol. 2014, 164, 907-921. [CrossRef]

51. Delvallé, D.; Dumez, S.; Wattebled, F.; Roldán, I.; Planchot, V.; Berbezy, P.; Colonna, P.; Vyas, D.; Chatterjee, M.; Ball, S.; et al. Soluble starch synthase I: A major determinant for the synthesis of amylopectin in Arabidopsis thaliana leaves. Plant J. 2005, 43, 398-412. [CrossRef]

52. Contado, C.; Wahlund, K.-G. High-Speed Separation and Size Characterization of Wheat and Barley Starch Granules by Lift-Hyperlayer Asymmetrical Flow Field-Flow Fractionation in Synergy with SPLITT Fractionation. Starch-Stärke 2006, 58, 140-154. [CrossRef]

53. Park, S.-H.; Wilson, J.D.; Seabourn, B.W. Starch granule size distribution of hard red winter and hard red spring wheat: Its effects on mixing and breadmaking quality. J. Cereal Sci. 2009, 49, 98-105. [CrossRef]

54. Ao, Z.; Jane, J.-1. Characterization and modeling of the A- and B-granule starches of wheat, triticale, and barley. Carbohydr. Polym. 2007, 67, 46-55. [CrossRef]

55. Matsushima, R.; Yamashita, J.; Kariyama, S.; Enomoto, T.; Sakamoto, W. A Phylogenetic Re-evaluation of Morphological Variations of Starch Grains among Poaceae Species. J. Appl. Glycosci. 2013, 60, 37-44. [CrossRef]

56. Saccomanno, B.; Chambers, A.H.; Hayes, A.; Mackay, I.; McWilliam, S.C.; Trafford, K. Starch granule morphology in oat endosperm. J. Cereal Sci. 2017, 73, 46-54. [CrossRef]

57. Kawagoe, Y. Special Issue "Starch Metabolism, Structure and Properties" The Characteristic Polyhedral, Sharp-edged Shape of Compound-type Starch Granules in Rice Endosperm is Achieved via the Septum-like Structure of the Amyloplast. J. Appl. Glycosci. 2013, 60, 29-36. [CrossRef]

58. Buttrose, M.S. Submicroscopic development and structure of starch granules in cereal endosperms. J. Ultrastruct. Res. 1960, 4, 231-257. [CrossRef]

59. Toyosawa, Y.; Kawagoe, Y.; Matsushima, R.; Crofts, N.; Ogawa, M.; Fukuda, M.; Kumamaru, T.; Okazaki, Y.; Kusano, M.; Saito, K.; et al. Deficiency of Starch Synthase IIIa and IVb Alters Starch Granule Morphology from Polyhedral to Spherical in Rice Endosperm. Plant Physiol. 2016, 170, 1255-1270. [CrossRef]

60. Ambigaipalan, P.; Hoover, R.; Donner, E.; Liu, Q.; Jaiswal, S.; Chibbar, R.; Nantanga, K.K.M.; Seetharaman, K. Structure of faba bean, black bean and pinto bean starches at different levels of granule organization and their physicochemical properties. Food Res. Int. 2011, 44, 2962-2974. [CrossRef] 
61. Blennow, A.; Hansen, M.; Schulz, A.; Jørgensen, K.; Donald, A.M.; Sanderson, J. The molecular deposition of transgenically modified starch in the starch granule as imaged by functional microscopy. J. Struct. Biol. 2003, 143, 229-241. [CrossRef]

62. Maaran, S.; Hoover, R.; Donner, E.; Liu, Q. Composition, structure, morphology and physicochemical properties of lablab bean, navy bean, rice bean, tepary bean and velvet bean starches. Food Chem. 2014, 152, 491-499. [CrossRef] [PubMed]

63. French, D. Fine Structure of Starch and its Relationship to the Organization of Starch Granules. J. Jpn. Soc. Starch Sci. 1972, 19, 8-25. [CrossRef]

64. Zhao, L.; Pan, T.; Guo, D.; Wei, C. A simple and rapid method for preparing the whole section of starchy seed to investigate the morphology and distribution of starch in different regions of seed. Plant Methods 2018, 14, 16. [CrossRef] [PubMed]

65. van de Velde, F.; van Riel, J.; Tromp, R.H. Visualisation of starch granule morphologies using confocal scanning laser microscopy (CSLM). J. Sci. Food Agric. 2002, 82, 1528-1536. [CrossRef]

66. Vandromme, C.; Kasprowicz, A.; Courseaux, A.; Trinel, D.; Facon, M.; Putaux, J.-L.; D’Hulst, C.; Wattebled, F.; Spriet, C. NegFluo, a Fast and Efficient Method to Determine Starch Granule Size and Morphology In Situ in Plant Chloroplasts. Front. Plant Sci. 2019, 10. [CrossRef]

67. Dürrenberger, M.B.; Handschin, S.; Conde-Petit, B.; Escher, F. Visualization of Food Structure by Confocal Laser Scanning Microscopy (CLSM). Lwt-Food Sci. Technol. 2001, 34, 11-17. [CrossRef]

68. Truernit, E.; Bauby, H.; Dubreucq, B.; Grandjean, O.; Runions, J.; Barthélémy, J.; Palauqui, J.-C. High-Resolution Whole-Mount Imaging of Three-Dimensional Tissue Organization and Gene Expression Enables the Study of Phloem Development and Structure in Arabidopsis. Plant Cell 2008, 20, 1494-1503. [CrossRef]

69. Horrer, D.; Flütsch, S.; Pazmino, D.; Matthews, J.S.A.; Thalmann, M.; Nigro, A.; Leonhardt, N.; Lawson, T.; Santelia, D. Blue Light Induces a Distinct Starch Degradation Pathway in Guard Cells for Stomatal Opening. Curr. Biol. 2016, 26, 362-370. [CrossRef]

70. Chen, P.; Yu, L.; Chen, L.; Li, X. Morphology and Microstructure of Maize Starches with Different Amylose/Amylopectin Content. Starch-Stärke 2006, 58, 611-615. [CrossRef]

71. Mahlow, S.; Hejazi, M.; Kuhnert, F.; Garz, A.; Brust, H.; Baumann, O.; Fettke, J. Phosphorylation of transitory starch by $\alpha$-glucan, water dikinase during starch turnover affects the surface properties and morphology of starch granules. New Phytol. 2014. [CrossRef]

72. Wang, S.; Yu, J.; Yu, J. Conformation and location of amorphous and semi-crystalline regions in C-type starch granules revealed by SEM, NMR and XRD. Food Chem. 2008, 110, 39-46. [CrossRef] [PubMed]

73. Barrera, G.N.; Calderón-Domínguez, G.; Chanona-Pérez, J.; Gutiérrez-López, G.F.; León, A.E.; Ribotta, P.D. Evaluation of the mechanical damage on wheat starch granules by SEM, ESEM, AFM and texture image analysis. Carbohydr. Polym. 2013, 98, 1449-1457. [CrossRef] [PubMed]

74. Blazek, J.; Gilbert, E.P. Application of small-angle X-ray and neutron scattering techniques to the characterisation of starch structure: A review. Carbohydr. Polym. 2011, 85, 281-293. [CrossRef]

75. Shrestha, A.K.; Blazek, J.; Flanagan, B.M.; Dhital, S.; Larroque, O.; Morell, M.K.; Gilbert, E.P.; Gidley, M.J. Molecular, mesoscopic and microscopic structure evolution during amylase digestion of maize starch granules. Carbohydr. Polym. 2012, 90, 23-33. [CrossRef] [PubMed]

76. Ellis, J.S.; Allen, S.; Chim, Y.T.A.; Roberts, C.J.; Tendler, S.J.B.; Davies, M.C. Molecular-Scale Studies on Biopolymers Using Atomic Force Microscopy. In Polymer Therapeutics II; Satchi-Fainaro, R., Duncan, R., Eds.; Springer: Berlin/Heidelberg, Germany, 2006; Volume 193, pp. 123-172.

77. An, H.; Liang, H.; Liu, Z.; Yang, H.; Liu, Q.; Wang, H. Nano-Structures of DeBranched Potato Starch Obtained by Isoamylolysis. J. Food Sci. 2010, 76, N11-N14. [CrossRef]

78. Baker, A.A.; Miles, M.J.; Helbert, W. Internal structure of the starch granule revealed by AFM. Carbohydr. Res. 2001, 330, 249-256. [CrossRef]

79. Hatta, T.; Nemoto, S.; Kainuma, K. A Surface Analytical Approach to the Structure of Starch Granules. J. Appl. Glycosci. 2003, 50, 159-162. [CrossRef]

80. Juszczak, L.; Fortuna, T.; Krok, F. Non-contact Atomic Force Microscopy of Starch Granules Surface. Part II. Selected Cereal Starches. Starch-Stärke 2003, 55, 8-16. [CrossRef]

81. Park, H.; Xu, S.; Seetharaman, K. A novel in situ atomic force microscopy imaging technique to probe surface morphological features of starch granules. Carbohydr. Res. 2011, 346, 847-853. [CrossRef] 
82. Waduge, R.N.; Xu, S.; Seetharaman, K. Iodine absorption properties and its effect on the crystallinity of developing wheat starch granules. Carbohydr. Polym. 2010, 82, 786-794. [CrossRef]

83. Zhu, F. Atomic Force Microscopy of Starch Systems. Crit. Rev. Food Sci. Nutr. 2015, 94, 3127-3144. [CrossRef]

84. Gao, M.; Xia, Q.; Akwe, A.W.; Stewart, L.; Ashu, G.M.; Njiti, V. Self-preserving lognormal volume-size distributions of starch granules in developing sweetpotatoes and modulation of their scale parameters by a starch synthase II (SSII). Acta Physiol. Plant. 2016, 38, 259. [CrossRef]

85. Ji, Q.; Oomen, R.J.F.J.; Vincken, J.-P.; Bolam, D.N.; Gilbert, H.J.; Suurs, L.C.J.M.; Visser, R.G.F. Reduction of starch granule size by expression of an engineered tandem starch-binding domain in potato plants. Plant Biotechnol. J. 2004, 2, 251-260. [CrossRef] [PubMed]

86. Campbell, M.; Li, J.; Berke, T.G.; Glover, D.V. Variation of Starch Granule Size in Tropical Maize Germ Plasm. Cereal Chem. 1996, 73, 536-538.

87. Huang, X.-F.; Nazarian-Firouzabadi, F.; Vincken, J.-P.; Ji, Q.; Visser, R.F.; Trindade, L. Expression of an amylosucrase gene in potato results in larger starch granules with novel properties. Planta 2014, 240, 409-421. [CrossRef] [PubMed]

88. Firouzabadi, F.; Vincken, J.-P.; Ji, Q.; Suurs, L.; Buléon, A.; Visser, R. Accumulation of multiple-repeat starch-binding domains (SBD2-SBD5) does not reduce amylose content of potato starch granules. Planta 2007, 225, 919-933. [CrossRef] [PubMed]

89. Warren, F.J.; Royall, P.G.; Gaisford, S.; Butterworth, P.J.; Ellis, P.R. Binding interactions of $\alpha$-amylase with starch granules: The influence of supramolecular structure and surface area. Carbohydr. Polym. 2011, 86, 1038-1047. [CrossRef]

90. Alvani, K.; Qi, X.; Tester, R.F.; Snape, C.E. Physico-chemical properties of potato starches. Food Chem. 2011, 125, 958-965. [CrossRef]

91. Yang, Y.-P.; Juang, Y.-S.; Hsu, B.-D. A quick method for assessing chloroplastic starch granules by flow cytometry. J. Plant Physiol. 2002, 159, 103-106. [CrossRef]

92. Clédat, D.; Battu, S.; Mokrini, R.; Cardot, P.J.P. Rice starch granule characterization by flow cytometry scattering techniques hyphenated with sedimentation field-flow fractionation. J. Chromatogr. A 2004, 1049, 131-138. [CrossRef]

93. Zhang, X.; Feng, J.; Wang, H.; Zhu, J.; Zhong, Y.; Liu, L.; Xu, S.; Zhang, R.; Zhang, X.; Xue, J.; et al. Bivariate flow cytometric analysis and sorting of different types of maize starch grains. Cytom. Part A 2018, 93, 213-221. [CrossRef] [PubMed]

94. Rolland-Sabaté, A.; Colonna, P.; Mendez-Montealvo, M.G.; Planchot, V. Branching Features of Amylopectins and Glycogen Determined by Asymmetrical Flow Field Flow Fractionation Coupled with Multiangle Laser Light Scattering. Biomacromolecules 2007, 8, 2520-2532. [CrossRef] [PubMed]

95. Vilaplana, F.; Gilbert, R.G. Analytical methodology for multidimensional size/branch-length distributions for branched glucose polymers using off-line 2-dimensional size-exclusion chromatography and enzymatic treatment. J. Chromatogr. A 2011, 1218, 4434-4444. [CrossRef] [PubMed]

96. Fernandez, C.; Rojas, C.C.; Nilsson, L. Size, structure and scaling relationships in glycogen from various sources investigated with asymmetrical flow field-flow fractionation and 1H NMR. Int. J. Biol. Macromol. 2011, 49, 458-465. [CrossRef]

97. Gilbert, R. Size-separation characterization of starch and glycogen for biosynthesis-structure-property relationships. Anal. Bioanal. Chem. 2011, 399, 1425-1438. [CrossRef]

98. Lopez-Rubio, A.; Flanagan, B.M.; Gilbert, E.P.; Gidley, M.J. A novel approach for calculating starch crystallinity and its correlation with double helix content: A combined XRD and NMR study. Biopolymers 2008, 89, 761-768. [CrossRef]

99. Morgan, K.R.; Furneaux, R.H.; Larsen, N.G. Solid-state NMR studies on the structure of starch granules. Carbohydr. Res. 1995, 276, 387-399. [CrossRef]

100. Jensen, S.L.; Larsen, F.H.; Bandsholm, O.; Blennow, A. Stabilization of semi-solid-state starch by branching enzyme-assisted chain-transfer catalysis at extreme substrate concentration. Biochem. Eng. J. 2013, 72, 1-10. [CrossRef]

101. Tan, I.; Flanagan, B.M.; Halley, P.J.; Whittaker, A.K.; Gidley, M.J. A Method for Estimating the Nature and Relative Proportions of Amorphous, Single, and Double-Helical Components in Starch Granules by $13 \mathrm{C}$ CP/MAS NMR. Biomacromolecules 2007, 8, 885-891. [CrossRef] 
102. Jodelet, A.; Rigby, N.M.; Colquhoun, I.J. Separation and NMR structural characterisation of singly branched Ît-dextrins which differ in the location of the branch point. Carbohydr. Res. 1998, 312, 139-151. [CrossRef]

103. Regina, A.; Blazek, J.; Gilbert, E.; Flanagan, B.M.; Gidley, M.J.; Cavanagh, C.; Ral, J.-P.; Larroque, O.; Bird, A.R.; $\mathrm{Li}, \mathrm{Z}$; et al. Differential effects of genetically distinct mechanisms of elevating amylose on barley starch characteristics. Carbohydr. Polym. 2012, 89, 979-991. [CrossRef] [PubMed]

104. Ritte, G.; Heydenreich, M.; Mahlow, S.; Haebel, S.; Kötting, O.; Steup, M. Phosphorylation of C6- and C3-positions of glucosyl residues in starch is catalysed by distinct dikinases. FEBS Lett. 2006, 580, 4872-4876. [CrossRef] [PubMed]

105. Schmieder, P.; Nitschke, F.; Steup, M.; Mallow, K.; Specker, E. Determination of glucan phosphorylation using heteronuclear $1 \mathrm{H}, 13 \mathrm{C}$ double and $1 \mathrm{H}, 13 \mathrm{C}, 31 \mathrm{P}$ triple-resonance NMR spectra. Magn. Reson. Chem. 2013, 51, 655-661. [CrossRef] [PubMed]

106. Schmitz, S.; Dona, A.C.; Castignolles, P.; Gilbert, R.G.; Gaborieau, M. Assessment of the Extent of Starch Dissolution in Dimethyl Sulfoxide by 1H NMR Spectroscopy. Macromol. Biosci. 2009, 9, 506-514. [CrossRef] [PubMed]

107. Yao, Y.; Ding, X. Pulsed Nuclear Magnetic Resonance (PNMR) Study of Rice Starch Retrogradation. Cereal Chem. J. 2002, 79, 751-756. [CrossRef]

108. Warren, F.J.; Gidley, M.J.; Flanagan, B.M. Infrared spectroscopy as a tool to characterise starch ordered structure-A joint FTIR-ATR, NMR, XRD and DSC study. Carbohydr. Polym. 2016, 139, 35-42. [CrossRef]

109. Nitschke, F.; Wang, P.; Schmieder, P.; Girard, J.-M.; Awrey, D.E.; Wang, T.; Israelian, J.; Zhao, X.; Turnbull, J.; Heydenreich, M.; et al. Hyperphosphorylation of Glucosyl C6 Carbons and Altered Structure of Glycogen in the Neurodegenerative Epilepsy Lafora Disease. Cell Metab. 2013, 17, 756-767. [CrossRef]

110. Ai, Y.; Jane, J.-1. Gelatinization and rheological properties of starch. Starch-Stärke 2015, 67, 213-224. [CrossRef]

111. Jane, J.; Chen, Y.Y.; Lee, L.F.; McPherson, A.E.; Wong, K.S.; Radosavljevic, M.; Kasemsuwan, T. Effects of Amylopectin Branch Chain Length and Amylose Content on the Gelatinization and Pasting Properties of Starch. Cereal Chem. J. 1999, 76, 629-637. [CrossRef]

112. Vamadevan, V.; Bertoft, E. Structure-function relationships of starch components. Starch-Stärke 2015, 67, 55-68. [CrossRef]

113. Schirmer, M.; Jekle, M.; Becker, T. Starch gelatinization and its complexity for analysis. Starch-Stärke 2015, 67, 30-41. [CrossRef]

114. Wu, A.C.; Li, E.; Gilbert, R.G. Exploring extraction/dissolution procedures for analysis of starch chain-length distributions. Carbohydr. Polym. 2014, 114, 36-42. [CrossRef] [PubMed]

115. Han, J.-A.; Lim, S.-T. Structural changes of corn starches by heating and stirring in DMSO measured by SEC-MALLS-RI system. Carbohydr. Polym. 2004, 55, 265-272. [CrossRef]

116. Ptaszek, A.; Ptaszek, P.; Dziubiński, M.; Grzesik, N.M.; Liszka-Skoczylas, M. The effect of structural properties on rheological behaviour of starches in binary dimethyl sulfoxide-water solutions. PLoS ONE 2017, 12, e0171109. [CrossRef] [PubMed]

117. Han, J.-A.; Lim, H.; Lim, S.-T. Comparison between Size Exclusion Chromatography and Micro-Batch Analyses of Corn Starches in DMSO using Light Scattering Detector. Starch-Stärke 2005, 57, 262-267. [CrossRef]

118. Jackson, D.S. Solubility Behavior of Granular Corn Starches in Methyl Sulfoxide (DMSO) as Measured by High Performance Size Exclusion Chromatography. Starch-Stärke 1991, 43, 422-427. [CrossRef]

119. Lee, J.H.; You, S.; Kweon, D.-K.; Chung, H.-J.; Lim, S.-T. Dissolution behaviors of waxy maize amylopectin in aqueous-DMSO solutions containing $\mathrm{NaCl}$ and $\mathrm{CaCl}$. Food Hydrocoll. 2014, 35, 115-121. [CrossRef]

120. Zhang, S.; Wang, C.; Fu, X.; Liu, H.; Yu, L.; Qiao, Q.; Jiang, T. A comparison study on phase transition and structure of cornstarch in dimethyl sulfoxide and ionic liquid systems. J. Cereal Sci. 2016, 71, 53-60. [CrossRef]

121. Hu, J.; Cheng, F.; Lin, Y.; Zhao, K.; Zhu, P. Dissolution of starch in urea/NaOH aqueous solutions. J. Appl. Polym. Sci. 2016, 133. [CrossRef]

122. Lin, M.; Shang, X.; Liu, P.; Xie, F.; Chen, X.; Sun, Y.; Wan, J. Zinc chloride aqueous solution as a solvent for starch. Carbohydr. Polym. 2016, 136, 266-273. [CrossRef]

123. Perez-Rea, D.; Bergenståhl, B.; Nilsson, L. Development and evaluation of methods for starch dissolution using asymmetrical flow field-flow fractionation. Part I: Dissolution of amylopectin. Anal. Bioanal. Chem. 2015, 407, 4315-4326. [CrossRef] [PubMed] 
124. Perez-Rea, D.; Bergenståhl, B.; Nilsson, L. Development and evaluation of methods for starch dissolution using asymmetrical flow field-flow fractionation. Part II: Dissolution of amylose. Anal. Bioanal. Chem. 2016, 408, 1399-1412. [CrossRef] [PubMed]

125. Ulbrich, M.; Salazar, M.L.; Flöter, E. Separation and molecular characterization of the amylose- and amylopectin-fraction from native and partially hydrolyzed potato starch. Starch-Stärke 2017, 69, 1600228. [CrossRef]

126. Doblado-Maldonado, A.F.; Gomand, S.V.; Goderis, B.; Delcour, J.A. The extent of maize starch crystal melting as a critical factor in the isolation of amylose via aqueous leaching. Food Hydrocoll. 2016, 61, 36-47. [CrossRef]

127. Doblado-Maldonado, A.F.; Janssen, F.; Gomand, S.V.; De Ketelaere, B.; Goderis, B.; Delcour, J.A. A response surface analysis of the aqueous leaching of amylose from maize starch. Food Hydrocoll. 2017, 63, $265-272$. [CrossRef]

128. Adkins, G.K.; Greenwood, C.T. The Isolation of Cereal Starches in the Laboratory. Starch-Stärke 1966, 18, 213-218. [CrossRef]

129. Mua, J.P.; Jackson, D.S. Fractionation of Regular Corn Starch: A Comparison of Aqueous Leaching and Aqueous Dispersion Methods. Cereal Chem. 1995, 72, 508-511.

130. Roger, P.; Colonna, P. Evidence of the presence of large aggregates contaminating amylose solutions. Carbohydr. Polym. 1993, 21, 83-89. [CrossRef]

131. Zhong, F.; Yokoyama, W.; Wang, Q.; Shoemaker, C.F. Rice Starch, Amylopectin, and Amylose: Molecular Weight and Solubility in Dimethyl Sulfoxide-Based Solvents. J. Agric. Food Chem. 2006, 54, 2320-2326. [CrossRef]

132. Banks, W.; Greenwood, C.T. Physicochemical Studies on Starches Part XXXII. The Incomplete $\beta$-Amylolysis of Amylose: A Discussion of its Cause and Implications. Starch-Stärke 1967, 19, 197-206. [CrossRef]

133. Zhu, F.; Corke, H.; Bertoft, E. Amylopectin internal molecular structure in relation to physical properties of sweetpotato starch. Carbohydr. Polym. 2011, 84, 907-918. [CrossRef]

134. Takeda, Y.; Hizukuri, S.; Juliano, B.O. Structures of rice amylopectins with low and high affinities for iodine. Carbohydr. Res. 1987, 168, 79-88. [CrossRef]

135. Charoenkul, N.; Uttapap, D.; Pathipanawat, W.; Takeda, Y. Simultaneous determination of amylose content \& unit chain distribution of amylopectins of cassava starches by fluorescent labeling/HPSEC. Carbohydr. Polym. 2006, 65, 102-108. [CrossRef]

136. Adkins, G.K.; Greenwood, C.T. Studies on starches of high amylose-content: Part X. An improved method for the fractionation of maize and amylomaize starches by complex formation from aqueous dispersion after pretreatment with methyl sulphoxide. Carbohydr. Res. 1969, 11, 217-224. [CrossRef]

137. Čeh, M.; Stropnik, Č.; Leskovar, S. Stufenweise Elutionsanalyse der Fraktionen von thermisch dispergierter Amylose-, Kartoffel- und Wachsmaisstärke. Starch-Stärke 1985, 37, 415-421. [CrossRef]

138. Banks, W.; Greenwood, C.T.; Muir, D.D. Studies on Starches of High Amylose-Content. Part 14. The Fractionation of Amylomaize Starch by Aqueous Leaching. Starch-Stärke 1971, 23, 199-201. [CrossRef]

139. Cornell, H.J.; McGrane, S.J.; Rix, C.J. A Novel and Rapid Method for the Partial Fractionation of Starch using 1-Butanol in the Presence of Thiocyanate. Starch-Stärke 1999, 51, 335-341. [CrossRef]

140. Li, D.; Zhu, F. Characterization of polymer chain fractions of kiwifruit starch. Food Chem. 2018, 240, 579-587. [CrossRef]

141. Yun, S.H.; Matheson, N.K. Estimation of Amylose Content of Starches after Precipitation of Amylopectin by Concanavalin-A. Starch-Stärke 1990, 42, 302-305. [CrossRef]

142. Gibson, T.S.; Solah, V.A.; McCleary, B.V. A Procedure to Measure Amylose in Cereal Starches and Flours with Concanavalin A. J. Cereal Sci. 1997, 25, 111-119. [CrossRef]

143. Matheson, N.K. A comparison of the structures of the fractions of normal and high-amylose pea-seed starches prepared by precipitation with concanavalin A. Carbohydr. Res. 1990, 199, 195-205. [CrossRef]

144. Matheson, N.K.; Welsh, L.A. Estimation and fractionation of the essentially unbranched (amylose) and branched (amylopectin) components of starches with concanavalin A. Carbohydr. Res. 1988, 180, 301-313. [CrossRef]

145. Goldstein, I.J.; Reichert, C.M.; Misaki, A. Interaction of Concanavalin A With Model Substrates. Ann. N. Y. Acad. Sci. 1974, 234, 283-296. [CrossRef]

146. Colonna, P.; Biton, V.; Mercier, C. Interactions of concanavalin A with $\alpha$-d-glucans. Carbohydr. Res. 1985, 137, 151-166. [CrossRef] 
147. Gomand, S.V.; Lamberts, L.; Derde, L.J.; Goesaert, H.; Vandeputte, G.E.; Goderis, B.; Visser, R.G.F.; Delcour, J.A. Structural properties and gelatinisation characteristics of potato and cassava starches and mutants thereof. Food Hydrocoll. 2010, 24, 307-317. [CrossRef]

148. Kurzawska, A.; Górecka, D.; Błaszczak, W.; Szwengiel, A.; Paukszta, D.; Lewandowicz, G. The molecular and supermolecular structure of common cattail (Typha latifolia) starch. Starch-Stärke 2014, 66, 849-856. [CrossRef]

149. Li, D.; Zhu, F. Physicochemical properties of kiwifruit starch. Food Chem. 2017, 220, 129-136. [CrossRef]

150. Luengwilai, K.; Beckles, D.M. Structural Investigations and Morphology of Tomato Fruit Starch. J. Agric. Food Chem. 2009, 57, 282-291. [CrossRef]

151. Li, G.; Zhu, F. Molecular structure of quinoa starch. Carbohydr. Polym. 2017, 158, 124-132. [CrossRef]

152. Forsyth, J.L.; Ring, S.G.; Noel, T.R.; Parker, R.; Cairns, P.; Findlay, K.; Shewry, P.R. Characterization of Starch from Tubers of Yam Bean (Pachyrhizus ahipa). J. Agric. Food Chem. 2002, 50, 361-367. [CrossRef]

153. Kobayashi, S.; Schwartz, S.J.; Lineback, D.R. Rapid analysis of starch, amylose and amylopectin by high-performance size-exclusion chromatography. J. Chromatogr. A 1985, 319, 205-214. [CrossRef]

154. Simsek, S.; Whitney, K.; Ohm, J.-B. Analysis of Cereal Starches by High-Performance Size Exclusion Chromatography. Food Anal. Methods 2013, 6, 181-190. [CrossRef]

155. Schwall, G.P.; Safford, R.; Westcott, R.J.; Jeffcoat, R.; Tayal, A.; Shi, Y.-C.; Gidley, M.J.; Jobling, S.A. Production of very-high-amylose potato starch by inhibition of SBE A and B. Nat. Biotechnol. 2000, 18, 551. [CrossRef] [PubMed]

156. Moorthy, S.N.; Andersson, L.; Eliasson, A.C.; Santacruz, S.; Ruales, J. Determination of Amylose Content in Different Starches Using Modulated Differential Scanning Calorimetry. Starch-Stärke 2006, 58, $209-214$. [CrossRef]

157. Dinges, J.R.; Colleoni, C.; Myers, A.M.; James, M.G. Molecular Structure of Three Mutations at the Maize sugary1 Locus and Their Allele-Specific Phenotypic Effects. Plant Physiol. 2001, 125, 1406-1418. [CrossRef]

158. Carciofi, M.; Blennow, A.; Jensen, S.; Shaik, S.; Henriksen, A.; Buleon, A.; Holm, P.; Hebelstrup, K. Concerted suppression of all starch branching enzyme genes in barley produces amylose-only starch granules. BMC Plant Biol. 2012, 12, 223. [CrossRef] [PubMed]

159. Hovenkamp-Hermelink, J.H.M.; De Vries, J.N.; Adamse, P.; Jacobsen, E.; Witholt, B.; Feenstra, W.J. Rapid estimation of the amylose/amylopectin ratio in small amounts of tuber and leaf tissue of the potato. Potato Res. 1988, 31, 241-246. [CrossRef]

160. McGrance, S.J.; Cornell, H.J.; Rix, C.J. A Simple and Rapid Colorimetric Method for the Determination of Amylose in Starch Products. Starch-Stärke 1998, 50, 158-163. [CrossRef]

161. Fox, J.D.; Robyt, J.F. Modification of starch granules by hydrolysis with hydrochloric acid in various alcohols, and the formation of new kinds of limit dextrins. Carbohydr. Res. 1992, 227, 163-170. [CrossRef]

162. Knutson, C.A. A Simplified Colorimetric Procedure for Determination of Amylose in Maize Starches. Cereal Chem. 1986, 63, 89-92.

163. Kaplan, F.; Guy, C.L. RNA interference of Arabidopsis beta-amylase8 prevents maltose accumulation upon cold shock and increases sensitivity of PSII photochemical efficiency to freezing stress. Plant J. 2005, 44, 730-743. [CrossRef] [PubMed]

164. Konik-Rose, C.; Thistleton, J.; Chanvrier, H.; Tan, I.; Halley, P.; Gidley, M.; Kosar-Hashemi, B.; Wang, H.; Larroque, O.; Ikea, J.; et al. Effects of starch synthase Ila gene dosage on grain, protein and starch in endosperm of wheat. Tag Theor. Appl. Genet. 2007, 115, 1053-1065. [CrossRef] [PubMed]

165. Hogg, A.C.; Gause, K.; Hofer, P.; Martin, J.M.; Graybosch, R.A.; Hansen, L.E.; Giroux, M.J. Creation of a high-amylose durum wheat through mutagenesis of starch synthase II (SSIIa). J. Cereal Sci. 2013, 57, 377-383. [CrossRef]

166. Cai, J.; Yang, Y.; Man, J.; Huang, J.; Wang, Z.; Zhang, C.; Gu, M.; Liu, Q.; Wei, C. Structural and functional properties of alkali-treated high-amylose rice starch. Food Chem. 2014, 145, 245-253. [CrossRef]

167. Nakamura, S.; Satoh, H.; Ohtsubo, K.i. Development of formulae for estimating amylose content, amylopectin chain length distribution, and resistant starch content based on the iodine absorption curve of rice starch. Biosci. Biotechnol. Biochem. 2015, 79, 443-455. [CrossRef]

168. Butardo, V.M.; Fitzgerald, M.A.; Bird, A.R.; Gidley, M.J.; Flanagan, B.M.; Larroque, O.; Resurreccion, A.P.; Laidlaw, H.K.C.; Jobling, S.A.; Morell, M.K.; et al. Impact of down-regulation of starch branching enzyme Ilb in rice by artificial microRNA- and hairpin RNA-mediated RNA silencing. J. Exp. Bot. 2011. [CrossRef] 
169. Duan, D.X.; Donner, E.; Liu, Q.; Smith, D.C.; Ravenelle, F. Potentiometric titration for determination of amylose content of starch-A comparison with colorimetric method. Food Chem. 2012, 130, 1142-1145. [CrossRef]

170. Williams, P.C.; Kuzina, F.D.; Hlynka, I. A rapid colorimetric procedure for estimating the amylose content of starches and flours. Cereal Chem. 1970, 47, 411-421, citeulike-article-id:7961057.

171. Morrison, W.R.; Laignelet, B. An improved colorimetric procedure for determining apparent and total amylose in cereal and other starches. J. Cereal Sci. 1983, 1, 9-20. [CrossRef]

172. Martinez, C.; Prodolliet, J. Determination of Amylose in Cereal and Non-Cereal Starches by a Colorimetric Assay: Collaborative Study. Starch-Stärke 1996, 48, 81-85. [CrossRef]

173. Suzuki, A.; Hizukuri, S.; Takeda, Y. Physicochemical Studies of Kuzu Starch. Cereal Chem. 1981, 58, $286-290$.

174. Duan, D.; Tu, Z.; Wang, H.; Sha, X.; Zhu, X. Physicochemical and rheological properties of modified rice amylose by dynamic high-pressure microfluidization. Int. J. Food Prop. 2017, 20, 734-744. [CrossRef]

175. Takeda, C.; Takeda, Y.; Hizukuri, S. Physicochemical Properties of Lily Starch. Cereal Chem. 1983, 60, $212-216$.

176. Yu, S.; Ma, Y.; Menager, L.; Sun, D.-W. Physicochemical Properties of Starch and Flour from Different Rice Cultivars. Food Bioprocess Technol 2012, 5, 626-637. [CrossRef]

177. Yoshimoto, Y.; Egashira, T.; Hanashiro, I.; Ohinata, H.; Takase, Y.; Takeda, Y. Molecular Structure and Some Physicochemical Properties of Buckwheat Starches. Cereal Chem. 2004, 81, 515-520. [CrossRef]

178. Tang, H.; Ando, H.; Watanabe, K.; Takeda, Y.; Mitsunaga, T. Physicochemical properties and structure of large, medium and small granule starches in fractions of normal barley endosperm. Carbohydr. Res. 2001, 330, 241-248. [CrossRef]

179. Liu, F.; Ahmed, Z.; Lee, E.A.; Donner, E.; Liu, Q.; Ahmed, R.; Morell, M.K.; Emes, M.J.; Tetlow, I.J. Allelic variants of the amylose extender mutation of maize demonstrate phenotypic variation in starch structure resulting from modified proteinâ€"protein interactions. J. Exp. Bot. 2012, 63, 1167-1183. [CrossRef]

180. Regina, A.; Kosar-Hashemi, B.; Li, Z.; Rampling, L.; Cmiel, M.; Gianibelli, M.C.; Konik-Rose, C.; Larroque, O.; Rahman, S.; Morell, M.K. Multiple isoforms of starch branching enzyme-I in wheat: Lack of the major SBE-I isoform does not alter starch phenotype. Funct. Plant Biol. 2004, 31, 591-601. [CrossRef]

181. Wang, J.; Li, Y.; Tian, Y.; Xu, X.; Ji, X.; Cao, X.; Jin, Z. A novel triple-wavelength colorimetric method for measuring amylose and amylopectin contents. Starch-Stärke 2010, 62, 508-516. [CrossRef]

182. Shi, Y.-C.; Capitani, T.; Trzasko, P.; Jeffcoat, R. Molecular Structure of a Low-Amylopectin Starch and Other High-Amylose Maize Starches. J. Cereal Sci. 1998, 27, 289-299. [CrossRef]

183. Larson, B.L.; Gilles, K.A.; Jenness, R. Amperometric Method for Determining Sorption of Iodine by Starch. Anal. Chem. 1953, 25, 802-804. [CrossRef]

184. Torruco-Uco, J.G.; Chávez-Murillo, C.E.; Hernández-Centeno, F.; Salgado-Delgado, R.; Tirado-Gallegos, J.M.; Zamudio-Flores, P.B. Use of High-Performance Size-Exclusion Chromatography for Characterization of Amylose Isolated from Diverse Botanical Sources. Int. J. Food Prop. 2016, 19, 1362-1369. [CrossRef]

185. Hizukuri, S.; Abe, J.-I.; Hanashiro, I. Starch: Analytical Aspects. In Carbohydrates in Food; Eliasson, A.-C., Ed.; CRC Press: Boca Raton, FL, USA, 2006; pp. 305-390. [CrossRef]

186. Lin, L.S.; Zhang, Q.; Zhang, L.; Wei, C.X. Evaluation of the Molecular Structural Parameters of Normal Rice Starch and Their Relationships with Its Thermal and Digestion Properties. Molecules 2017, 22, 1526. [CrossRef]

187. Yamamori, M.; Fujita, S.; Hayakawa, K.; Matsuki, J.; Yasui, T. Genetic elimination of a starch granule protein, SGP-1, of wheat generates an altered starch with apparent high amylose. Appl. Genet. 2000, 101, 21-29. [CrossRef]

188. Lin, L.; Guo, D.; Zhao, L.; Zhang, X.; Wang, J.; Zhang, F.; Wei, C. Comparative structure of starches from high-amylose maize inbred lines and their hybrids. Food Hydrocoll. 2016, 52, 19-28. [CrossRef]

189. Klucinec, J.; Thompson, D.B. Fractionation of high-amylose maize starches by differential alcohol precipitation and chromatography of the fractions. Cereal Chem. 1998, 75. [CrossRef]

190. Banks, W.; Greenwood, C.T.; Muir, D.D. The Characterization of Starch and Its Components. Part 6. A Critical Comparison of the Estimation of Amylose-Content by Colorimetric Determination and Potentiometric Titration of the Iodine-Complex. Starch-Stärke 1974, 26, 73-78. [CrossRef]

191. Malinova, I.; Steup, M.; Fettke, J. Carbon transitions from either Calvin cycle or transitory starch to heteroglycans as revealed by ${ }^{14} \mathrm{C}$-labeling experiments using protoplasts from Arabidopsis. Physiol. Plant. 2013, 149, 25-44. [CrossRef]

192. Smith, A.M.; Zeeman, S.C. Quantification of starch in plant tissues. Nat. Protoc. 2006, 1, 1342. [CrossRef] 
193. Bertoft, E. Chapter 2-Analyzing Starch Molecular Structure. In Starch in Food, 2nd ed.; Sjöö, M., Nilsson, L., Eds.; Woodhead Publishing: Cambridge, UK, 2018; pp. 97-149. [CrossRef]

194. Malinova, I.; Mahto, H.; Brandt, F.; AL-Rawi, S.; Qasim, H.; Brust, H.; Hejazi, M.; Fettke, J. EARLY STARVATION1 specifically affects the phosphorylation action of starch-related dikinases. Plant J. 2018, 95, 126-137. [CrossRef]

195. Fettke, J.; Albrecht, T.; Hejazi, M.; Mahlow, S.; Nakamura, Y.; Steup, M. Glucose 1-phosphate is efficiently taken up by potato (Solanum tuberosum) tuber parenchyma cells and converted to reserve starch granules. New Phytol. 2010, 185, 663-675. [CrossRef]

196. Edner, C.; Li, J.; Albrecht, T.; Mahlow, S.; Hejazi, M.; Hussain, H.; Kaplan, F.; Guy, C.; Smith, S.M.; Steup, M.; et al. Glucan, Water Dikinase Activity Stimulates Breakdown of Starch Granules by Plastidial beta-Amylases. Plant Physiol. 2007, 145, 17-28. [CrossRef] [PubMed]

197. Hejazi, M.; Fettke, J.; Haebel, S.; Edner, C.; Paris, O.; Frohberg, C.; Steup, M.; Ritte, G. Glucan, water dikinase phosphorylates crystalline maltodextrins and thereby initiates solubilization. Plant J. 2008, 55, 323-334. [CrossRef] [PubMed]

198. Hejazi, M.; Fettke, J.; Kötting, O.; Zeeman, S.C.; Steup, M. The Laforin-Like Dual-Specificity Phosphatase SEX4 from Arabidopsis Hydrolyzes Both C6- and C3-Phosphate Esters Introduced by Starch-Related Dikinases and Thereby Affects Phase Transition of ÎI-Glucans. Plant Physiol. 2010, 152, 711-722. [CrossRef] [PubMed]

199. Hejazi, M.; Mahlow, S.; Fettke, J. The glucan phosphorylation mediated by $\alpha$-glucan, water dikinase (GWD) is also essential in the light phase for a functional transitory starch turn-over. Plant Signal. Behav. 2014, 9, e28892. [CrossRef] [PubMed]

200. Mahlow, S.; Orzechowski, S.; Fettke, J. Starch phosphorylation: Insights and perspectives. Cell. Mol. Life Sci. 2016, 73, 2753-2764. [CrossRef]

201. Hejazi, M.; Steup, M.; Fettke, J. The plastidial glucan, water dikinase (GWD) catalyses multiple phosphotransfer reactions. FEBS J. 2012, 279, 1953-1966. [CrossRef] [PubMed]

202. Castro, J.V.; Ward, R.M.; Gilbert, R.G.; Fitzgerald, M.A. Measurement of the Molecular Weight Distribution of Debranched Starch. Biomacromolecules 2005, 6, 2260-2270. [CrossRef]

203. Cave, R.A.; Seabrook, S.A.; Gidley, M.J.; Gilbert, R.G. Characterization of Starch by Size-Exclusion Chromatography: The Limitations Imposed by Shear Scission. Biomacromolecules 2009, 10, 2245-2253. [CrossRef]

204. Sullivan, M.A.; Vilaplana, F.; Cave, R.A.; Stapleton, D.; Gray-Weale, A.A.; Gilbert, R.G. Nature of $\alpha$ and $\beta$ Particles in Glycogen Using Molecular Size Distributions. Biomacromolecules 2010, 11, 1094-1100. [CrossRef]

205. Gilbert, R.G.; Sullivan, M.A. The Molecular Size Distribution of Glycogen and its Relevance to Diabetes. Aust. J. Chem. 2014, 67, 538-543. [CrossRef]

206. Rübsam, H.; Krottenthaler, M.; Gastl, M.; Becker, T. An overview of separation methods in starch analysis: The importance of size exclusion chromatography and field flow fractionation. Starch-Stärke 2012, 64, 683-695. [CrossRef]

207. Ciric, J.; Oostland, J.; de Vries, J.W.; Woortman, A.J.J.; Loos, K. Size Exclusion Chromatography with Multi Detection in Combination with Matrix-Assisted Laser Desorption Ionization-Time-of-Flight Mass Spectrometry as a Tool for Unraveling the Mechanism of the Enzymatic Polymerization of Polysaccharides. Anal. Chem. 2012, 84, 10463-10470. [CrossRef]

208. Ciric, J.; Woortman, A.J.J.; Loos, K. Analysis of isoamylase debranched starches with size exclusion chromatography utilizing PFG columns. Carbohydr. Polym. 2014, 112, 458-461. [CrossRef] [PubMed]

209. Hasjim, J.; Lavau, G.C.; Gidley, M.J.; Gilbert, R.G. In Vivo and In Vitro Starch Digestion: Are Current in Vitro Techniques Adequate? Biomacromolecules 2010, 11, 3600-3608. [CrossRef] [PubMed]

210. Hernández, J.M.; Gaborieau, M.; Castignolles, P.; Gidley, M.J.; Myers, A.M.; Gilbert, R.G. Mechanistic Investigation of a Starch-Branching Enzyme Using Hydrodynamic Volume SEC Analysis. Biomacromolecules 2008, 9, 954-965. [CrossRef]

211. Hoang, N.-L.; Landolfi, A.; Kravchuk, A.; Girard, E.; Peate, J.; Hernandez, J.M.; Gaborieau, M.; Kravchuk, O.; Gilbert, R.G.; Guillaneuf, Y.; et al. Toward a full characterization of native starch: Separation and detection by size-exclusion chromatography. J. Chromatogr. A 2008, 1205, 60-70. [CrossRef] [PubMed]

212. Motawia, M.S.; Damager, I.; Olsen, C.E.; Møller, B.L.; Engelsen, S.B.; Hansen, S.; Øgendal, L.H.; Bauer, R. Comparative Study of Small Linear and Branched Alpha-Glucans Using Size Exclusion Chromatography and Static and Dynamic Light Scattering. Biomacromolecules 2005, 6, 143-151. [CrossRef] [PubMed] 
213. Ovando-Martínez, M.; Whitney, K.; Simsek, S. Analysis of Starch in Food Systems by High-Performance Size Exclusion Chromatography. J. Food Sci. 2013, 78, C192-C198. [CrossRef]

214. Podzimek, S. Truths and myths about the determination of molar mass distribution of synthetic and natural polymers by size exclusion chromatography. J. Appl. Polym. Sci. 2014, 131. [CrossRef]

215. Déjardin, P. Determination of the functioning parameters in asymmetrical flow field-flow fractionation with an exponential channel. J. Chromatogr. A 2013, 1305, 213-220. [CrossRef] [PubMed]

216. Krebs, G.; Becker, T.; Gastl, M. Characterization of polymeric substance classes in cereal-based beverages using asymmetrical flow field-flow fractionation with a multi-detection system. Anal. Bioanal. Chem. 2017, 409, 5723-5734. [CrossRef]

217. Malik, M.I.; Pasch, H. Field-flow fractionation: New and exciting perspectives in polymer analysis. Prog. Polym. Sci. 2016, 63, 42-85. [CrossRef]

218. Kowalkowski, T.; Buszewski, B.; Cantado, C.; Dondi, F. Field-Flow Fractionation: Theory, Techniques, Applications and the Challenges. Crit. Rev. Anal. Chem. 2006, 36, 129-135. [CrossRef]

219. Wahlund, K.-G. Flow field-flow fractionation: Critical overview. J. Chromatogr. A 2013, 1287, 97-112. [CrossRef] [PubMed]

220. Yokoyama, W.; Renner-Nantz, J.J.; Shoemaker, C.F. Starch Molecular Mass and Size by Size-Exclusion Chromatography in DMSO-LiBr Coupled with Multiple Angle Laser Light Scattering. Cereal Chem. 1998, 75, 530-535. [CrossRef]

221. Chen, Y.; Fringant, C.; Rinaudo, M. Molecular characterization of starch by SEC: Dependance of the performances on the amylopectin content. Carbohydr. Polym. 1997, 33, 73-78. [CrossRef]

222. Sullivan, M.A.; Powell, P.O.; Witt, T.; Vilaplana, F.; Roura, E.; Gilbert, R.G. Improving size-exclusion chromatography separation for glycogen. J. Chromatogr. A 2014, 1332, 21-29. [CrossRef]

223. Rolland-Sabaté, A.; Guilois, S.; Jaillais, B.; Colonna, P. Molecular size and mass distributions of native starches using complementary separation methods: Asymmetrical Flow Field Flow Fractionation (A4F) and Hydrodynamic and Size Exclusion Chromatography (HDC-SEC). Anal. Bioanal. Chem. 2011, 399, 1493-1505. [CrossRef]

224. Rübsam, H.; Gastl, M.; Becker, T. Determination of the influence of starch sources and mashing procedures on the range of the molecular weight distribution of beer using field-flow fractionation. J. Inst. Brew. 2013, 119, 139-148. [CrossRef]

225. Brust, H.; Lehmann, T.; D'Hulst, C.; Fettke, J. Analysis of the Functional Interaction of Arabidopsis Starch Synthase and Branching Enzyme Isoforms Reveals that the Cooperative Action of SSI and BEs Results in Glucans with Polymodal Chain Length Distribution Similar to Amylopectin. PLoS ONE 2014, 9, e102364. [CrossRef] [PubMed]

226. Pfister, B.; Lu, K.-J.; Eicke, S.; Feil, R.; Lunn, J.E.; Streb, S.; Zeeman, S.C. Genetic Evidence That Chain Length and Branch Point Distributions Are Linked Determinants of Starch Granule Formation in Arabidopsis. Plant Physiol. 2014, 165, 1457-1474. [CrossRef]

227. Szydlowski, N.; Ragel, P.; Hennen-Bierwagen, T.A.; Planchot, V.; Myers, A.M.; Mérida, A.; d'Hulst, C.; Wattebled, F. Integrated functions among multiple starch synthases determine both amylopectin chain length and branch linkage location in Arabidopsis leaf starch. J. Exp. Bot. 2011. [CrossRef] [PubMed]

228. Szydlowski, N.; Ragel, P.; Raynaud, S.; Lucas, M.M.; Roldán, I.; Montero, M.; Muñoz, F.J.; Ovecka, M.; Bahaji, A.; Planchot, V;; et al. Starch Granule Initiation in Arabidopsis Requires the Presence of Either Class IV or Class III Starch Synthases. Plant Cell 2009, 21, 2443-2457. [CrossRef] [PubMed]

229. Umemoto, T.; Aoki, N.; Lin, H.; Nakamura, Y.; Inouchi, N.; Sato, Y.; Yano, M.; Hirabayashi, H.; Maruyama, S. Natural variation in rice starch synthase IIa affects enzyme and starch properties. Funct. Plant Biol. 2004, 31, 671-684. [CrossRef]

230. Nishi, A.; Nakamura, Y.; Tanaka, N.; Satoh, H. Biochemical and Genetic Analysis of the Effects of Amylose-Extender Mutation in Rice Endosperm. Plant Physiol. 2001, 127, 459-472. [CrossRef]

231. Park, E.; Yang, H.; Kim, Y.; Kim, J. Analysis of oligosaccharides in beer using MALDI-TOF-MS. Food Chem. 2012, 134, 1658-1664. [CrossRef]

232. Harvey, D.J. Analysis of carbohydrates and glycoconjugates by matrix-assisted laser desorption/ionization mass spectrometry: An update for 2007-2008. Mass Spectrom. Rev. 2012, 31, 183-311. [CrossRef]

233. Ritte, G.; Scharf, A.; Eckermann, N.; Haebel, S.; Steup, M. Phosphorylation of Transitory Starch Is Increased during Degradation. Plant Physiol. 2004, 135, 2068-2077. [CrossRef] 
234. Tagliabracci, V.S.; Heiss, C.; Karthik, C.; Contreras, C.J.; Glushka, J.; Ishihara, M.; Azadi, P.; Hurley, T.D.; DePaoli-Roach, A.A.; Roach, P.J. Phosphate Incorporation during Glycogen Synthesis and Lafora Disease. Cell Metab. 2011, 13, 274-282. [CrossRef]

235. Stapleton, D.; Nelson, C.; Parsawar, K.; McClain, D.; Gilbert-Wilson, R.; Barker, E.; Rudd, B.; Brown, K.; Hendrix, W.; O’Donnell, P.; et al. Analysis of Hepatic Glycogen-Associated Proteins. Proteomics 2010, 10, 2320-2329. [CrossRef] [PubMed]

236. Tan, X.; Sullivan, M.A.; Nada, S.S.; Deng, B.; Schulz, B.L.; Gilbert, R.G. Proteomic Investigation of the Binding Agent between Liver Glycogen $\beta$ Particles. ACS Omega 2018, 3, 3640-3645. [CrossRef] [PubMed]

237. Stapleton, D.; Nelson, C.; Parsawar, K.; Flores-Opazo, M.; McClain, D.; Parker, G. The 3T3-L1 adipocyte glycogen proteome. Proteome Sci. 2013, 11, 11. [CrossRef] [PubMed]

238. Wang, J.; Stuckey, J.A.; Wishart, M.J.; Dixon, J.E. A Unique Carbohydrate Binding Domain Targets the Lafora Disease Phosphatase to Glycogen. J. Biol. Chem. 2002, 277, 2377-2380. [CrossRef] [PubMed]

239. Xing, S.; Meng, X.; Zhou, L.; Mujahid, H.; Zhao, C.; Zhang, Y.; Wang, C.; Peng, Z. Proteome Profile of Starch Granules Purified from Rice (Oryza sativa) Endosperm. PLoS ONE 2016, 11, e0168467. [CrossRef] [PubMed]

240. Koziol, A.G.; Marquez, B.K.; Huebsch, M.P.; Smith, J.C.; Altosaar, I. The starch granule associated proteomes of commercially purified starch reference materials from rice and maize. J. Proteom. 2012, 75, 993-1003. [CrossRef]

241. Helle, S.; Bray, F.; Verbeke, J.; Devassine, S.; Courseaux, A.; Facon, M.; Tokarski, C.; Rolando, C.; Szydlowski, N. Proteome Analysis of Potato Starch Reveals the Presence of New Starch Metabolic Proteins as Well as Multiple Protease Inhibitors. Front. Plant Sci. 2018, 9. [CrossRef]

242. Liu, F.; Makhmoudova, A.; Lee, E.A.; Wait, R.; Emes, M.J.; Tetlow, I.J. The amylose extender mutant of maize conditions novel protein-protein interactions between starch biosynthetic enzymes in amyloplasts. J. Exp. Bot. 2009, erp297. [CrossRef]

243. Grimaud, F.; Rogniaux, H.; James, M.G.; Myers, A.M.; Planchot, V. Proteome and phosphoproteome analysis of starch granule-associated proteins from normal maize and mutants affected in starch biosynthesis. J. Exp. Bot. 2008, 59, 3395-3406. [CrossRef]

244. Butardo, V.M.; Daygon, V.D.; Colgrave, M.L.; Campbell, P.M.; Resurreccion, A.; Cuevas, R.P.; Jobling, S.A.; Tetlow, I.; Rahman, S.; Morell, M.; et al. Biomolecular Analyses of Starch and Starch Granule Proteins in the High-Amylose Rice Mutant Goami 2. J. Agric. Food Chem. 2012, 60, 11576-11585. [CrossRef]

245. Yu, H.; Wang, T. Proteomic Dissection of Endosperm Starch Granule Associated Proteins Reveals a Network Coordinating Starch Biosynthesis and Amino Acid Metabolism and Glycolysis in Rice Endosperms. Front. Plant Sci. 2016, 7. [CrossRef] [PubMed]

246. Denyer, K.A.Y.; Johnson, P.; Zeeman, S.; Smith, A.M. The control of amylose synthesis. J. Plant Physiol. 2001, 158, 479-487. [CrossRef]

247. Edwards, A.; Vincken, J.-P.; Suurs, L.C.J.M.; Visser, R.G.F.; Zeeman, S.; Smith, A.; Martin, C. Discrete Forms of Amylose Are Synthesized by Isoforms of GBSSI in Pea. Plant Cell 2002, 14, 1767-1785. [CrossRef]

248. Vrinten, P.L.; Nakamura, T. Wheat Granule-Bound Starch Synthase I and II Are Encoded by Separate Genes That Are Expressed in Different Tissues. Plant Physiol. 2000, 122, 255-264. [CrossRef] [PubMed]

249. Park, Y.-J.; Nemoto, K.; Nishikawa, T.; Matsushima, K.; Minami, M.; Kawase, M. Molecular cloning and characterization of granule bound starch synthase I cDNA from a grain amaranth (Amaranthus cruentus L.). Breed. Sci. 2009, 59, 351-360. [CrossRef]

250. Rohde, W.; Becker, D.; Salamini, F. Structural analysis of the waxy locus from Hordeum vulgare. Nucleic Acids Res. 1988, 16, 7185. [CrossRef]

251. Asare, E.K.; Båga, M.; Rossnagel, B.G.; Chibbar, R.N. Polymorphism in the Barley Granule Bound Starch Synthase 1 (Gbss1) Gene Associated with Grain Starch Variant Amylose Concentration. J. Agric. Food Chem. 2012, 60, 10082-10092. [CrossRef]

252. Shure, M.; Wessler, S.; Fedoroff, N. Molecular identification and isolation of the Waxy locus in maize. Cell 1983, 35, 225-233. [CrossRef]

253. Klosgen, R.B.; Gierl, A.; Schwarzsommer, Z.; Saedler, H. Molecular analysis of the waxy locus of Zea mays. Mol. Gen. Genet. 1986, 203, 237-244. [CrossRef]

254. Denyer, K.; Barber, L.M.; Burton, R.; Hedley, C.L.; Hylton, C.M.; Johnson, S.; Jones, D.A.; Marshall, J.; Smith, A.M.; Tatge, H.; et al. The isolation and characterization of novel low-amylose mutants of Pisum sativum L. Plant Cell Environ. 1995, 18, 1019-1026. 
255. Hovenkamp-Hermelink, J.H.M.; Jacobsen, E.; Ponstein, A.S.; Visser, R.G.F.; Vos-Scheperkeuter, G.H.; Bijmolt, E.W.; de Vries, J.N.; Witholt, B.; Feenstra, W.J. Isolation of an amylose-free starch mutant of the potato (Solanum tuberosum L.). Appl. Genet. 1987, 75, 217-221. [CrossRef]

256. Wang, Z.Y.; Zheng, F.Q.; Shen, G.Z.; Gao, J.P.; Snustad, D.P.; Li, M.G.; Zhang, J.L.; Hong, M.M. The amylose content in rice endosperm is related to the posttranscriptional regulation of the waxy gene. Plant J. 1995, 7. [CrossRef]

257. Kozlov, S.S.; Noda, T.; Bertoft, E.; Yuryev, V.P. Structure of starches extracted from near isogenic wheat lines. J. Anal. Calorim. 2006, 86, 291-301. [CrossRef]

258. Nakamura, T.; Yamamori, M.; Hirano, H.; Hidaka, S.; Nagamine, T. Production of waxy (amylose-free) wheats. Mol. Gen. Genet. MGG 1995, 248, 253-259. [CrossRef] [PubMed]

259. Feike, D.; Seung, D.; Graf, A.; Bischof, S.; Ellick, T.; Coiro, M.; Soyk, S.; Eicke, S.; Mettler-Altmann, T.; Lu, K.J.; et al. The Starch Granule-Associated Protein EARLY STARVATION1 Is Required for the Control of Starch Degradation in Arabidopsis thaliana Leaves. Plant Cell 2016, 28, 1472-1489. [CrossRef]

260. Peng, C.; Wang, Y.; Liu, F.; Ren, Y.; Zhou, K.; Lv, J.; Zheng, M.; Zhao, S.; Zhang, L.; Wang, C.; et al. FLOURY ENDOSPERM6 encodes a CBM48 domain-containing protein involved in compound granule formation and starch synthesis in rice endosperm. Plant J. 2014, 77, 917-930. [CrossRef] [PubMed]

261. Seung, D.; Soyk, S.; Coiro, M.; Maier, B.A.; Eicke, S.; Zeeman, S.C. PROTEIN TARGETING TO STARCH Is Required for Localising GRANULE-BOUND STARCH SYNTHASE to Starch Granules and for Normal Amylose Synthesis in Arabidopsis. PLoS Biol. 2015, 13, e1002080. [CrossRef]

262. Denyer, K.; Sidebottom, C.; Hylton, C.M.; Smith, A.M. Soluble isoforms of starch synthase and starch-branching enzyme also occur within starch granules in developing pea embryos. Plant J. 1993, 4, 191-198. [CrossRef]

263. Stensballe, A.; Hald, S.; Bauw, G.; Blennow, A.; Welinder, K.G. The amyloplast proteome of potato tuber. FEBS J. 2008, 275, 1723-1741. [CrossRef]

264. Larsson, C.-T.; Hofvander, P.; Khoshnoodi, J.; Ek, B.; Rask, L.; Larsson, H.k. Three isoforms of starch synthase and two isoforms of branching enzyme are present in potato tuber starch. Plant Sci. 1996, 117, 9-16. [CrossRef]

265. Peng, M.; Gao, M.; Baga, M.; Hucl, P.; Chibbar, R.N. Starch-Branching Enzymes Preferentially Associated with A-Type Starch Granules in Wheat Endosperm. Plant Physiol. 2000, 124, 265-272. [CrossRef] [PubMed]

266. Umemoto, T.; Aoki, N. Single-nucleotide polymorphisms in rice starch synthase IIa that alter starch gelatinisation and starch association of the enzyme. Funct. Plant Biol. 2005, 32, 763-768. [CrossRef]

267. Mu-Forster, C.; Huang, R.; Powers, J.R.; Harriman, R.W.; Knight, M.; Singletary, G.W.; Keeling, P.L.; Wasserman, B.P. Physical Association of Starch Biosynthetic Enzymes with Starch Granules of Maize Endosperm (Granule-Associated Forms of Starch Synthase I and Starch Branching Enzyme II). Plant Physiol. 1996, 111, 821-829. [CrossRef] [PubMed]

268. Regina, A.; Kosar-Hashemi, B.; Li, Z.; Pedler, A.; Mukai, Y.; Yamamoto, M.; Gale, K.; Sharp, P.; Morell, M.; Rahman, S. Starch branching enzyme IIb in wheat is expressed at low levels in the endosperm compared to other cereals and encoded at a non-syntenic locus. Planta 2005, 222, 899-909. [CrossRef] [PubMed]

269. Zhong, Y.; Blennow, A.; Kofoed-Enevoldsen, O.; Jiang, D.; Hebelstrup, K.H. Protein Targeting to Starch 1 is essential for starchy endosperm development in barley. J. Exp. Bot. 2019, 70, 485-496. [CrossRef] [PubMed]

270. Schreier, T.B.; Umhang, M.; Lee, S.-K.; Lue, W.-L.; Shen, Z.; Silver, D.; Graf, A.; Müller, A.; Eicke, S.; Stadler-Waibel, M.; et al. LIKE SEX4 1 Acts as a $\beta$-Amylase-Binding Scaffold on Starch Granules during Starch Degradation. Plant Cell 2019, 31, 2169-2186. [CrossRef]

271. Raynaud, S.; Ragel, P.; Rojas, T.; Mérida, Á. The N-terminal Part of Arabidopsis thaliana Starch Synthase 4 Determines the Localization and Activity of the Enzyme. J. Biol. Chem. 2016, 291, 10759-10771. [CrossRef]

272. Chanzy, H.; Putaux, J.-L.; Dupeyre, D.; Davies, R.; Burghammer, M.; Montanari, S.; Riekel, C. Morphological and structural aspects of the giant starch granules from Phajus grandifolius. J. Struct. Biol. 2006, 154, 100-110. [CrossRef]

(C) 2020 by the authors. Licensee MDPI, Basel, Switzerland. This article is an open access article distributed under the terms and conditions of the Creative Commons Attribution (CC BY) license (http://creativecommons.org/licenses/by/4.0/). 